The Cryosphere, 6, 1-19, 2012

www.the-cryosphere.net/6/1/2012/

doi:10.5194/tc-6-1-2012

(c) Author(s) 2012. CC Attribution 3.0 License.

\title{
Hydrologic controls on coastal suspended sediment plumes around the Greenland Ice Sheet
}

\author{
V. W. Chu ${ }^{1}$, L. C. Smith ${ }^{1}$, A. K. Rennermalm ${ }^{2}$, R. R. Forster ${ }^{3}$, and J. E. Box ${ }^{4,5}$ \\ ${ }^{1}$ Department of Geography, University of California, Los Angeles, 1255 Bunche Hall, 951524, Los Angeles, CA 90095, USA \\ ${ }^{2}$ Department of Geography, Rutgers, The State University of New Jersey, 54 Joyce Kilmer Avenue, Piscataway, New Jersey \\ 08854, USA \\ ${ }^{3}$ Department of Geography, University of Utah, 260 S. Central Campus Dr., Salt Lake City, UT 84112, USA \\ ${ }^{4}$ Department of Geography, The Ohio State University, 1036 Derby Hall, 154 North Oval Mall, Columbus, OH 43210, USA \\ ${ }^{5}$ Byrd Polar Research Center, The Ohio State University, 1090 Carmack Rd., Columbus, OH 43210, USA \\ Correspondence to: V. W. Chu (venachu@ucla.edu)
}

Received: 22 August 2011 - Published in The Cryosphere Discuss.: 12 September 2011

Revised: 28 November 2011 - Accepted: 5 December 2011 - Published: 4 January 2012

\begin{abstract}
Rising sea levels and increased surface melting of the Greenland ice sheet have heightened the need for direct observations of meltwater release from the ice edge to ocean. Buoyant sediment plumes that develop in fjords downstream of outlet glaciers are controlled by numerous factors, including meltwater runoff. Here, Moderate Resolution Imaging Spectroradiometer (MODIS) satellite imagery is used to average surface suspended sediment concentration (SSC) in fjords around $\sim 80 \%$ of Greenland from 2000-2009. Spatial and temporal patterns in SSC are compared with positivedegree-days (PDD), a proxy for surface melting, from the Polar MM5 regional climate model. Over this decade significant geographic covariance occurred between ice sheet PDD and fjord SSC, with outlet type (land- vs. marine-terminating glaciers) also important. In general, high SSC is associated with high PDD and/or a high proportion of land-terminating glaciers. Unlike previous site-specific studies of the Watson River plume at Kangerlussuaq, temporal covariance is low, suggesting that plume dimensions best capture interannual runoff dynamics whereas SSC allows assessment of meltwater signals across much broader fjord environments around the ice sheet. Remote sensing of both plume characteristics thus offers a viable approach for observing spatial and temporal patterns of meltwater release from the Greenland ice sheet to the global ocean.
\end{abstract}

\section{Introduction}

The Greenland ice sheet is undergoing increasing melt intensity and extent (Mote, 2007; Bhattacharya et al., 2009); in response to warming air temperatures (Hanna et al., 2008; Tedesco et al., 2008; Box et al., 2009). Ice mass loss has accelerated in the last decade (Chen et al., 2006; Rignot et al., 2008), with increasing accumulation in the ice sheet interior (Box et al., 2006; Burgess et al., 2010) exceeded by losses in the marginal ablation zone (Luthcke et al., 2006; Ettema et al., 2009). Losses are exponentially higher at the margin (van den Broeke et al., 2008) with rapid thinning of near-coastal outlet glaciers (Krabill et al., 2004; Pritchard et al., 2009). Marine-terminating outlet glaciers have also shown increases in total ice discharge (Rignot et al., 2004; Howat et al., 2007) and velocity (Rignot and Kanagaratnam, 2006; Joughin et al., 2010), with accelerated ice loss recently extending to the northwest (Khan et al., 2010). By the end of this century, Greenland's contribution to global sea level rise may total $\sim 17-54 \mathrm{~cm}$ (Pfeffer et al., 2008), and perhaps reach an annual rate $\sim 0.7-0.8 \mathrm{~mm} \mathrm{yr}^{-1}$ (Fettweis et al., 2008).

While ice discharge is the primary form of mass loss for most marine-terminating outlet glaciers (Mernild et al., 2010), meltwater runoff possibly contributes more than half the total mass loss for the ice sheet as a whole (van den Broeke et al., 2009). Mass-loss estimates using GRACE 
gravity data also require knowledge of meltwater runoff, but must currently use modeled estimates rather than direct observations (Velicogna, 2009). Increased meltwater production has been linked to ice velocity increases in fast moving outlet glaciers (Joughin et al., 1996; Shepherd et al., 2009; Andersen et al., 2010), as well as seasonal speedups of the broader, slower moving ice sheet (Joughin et al., 2008; van de Wal et al., 2008; Palmer et al., 2011). Meltwater can be transported to the bed through moulins and possibly welldeveloped englacial drainage networks (Catania and Neumann, 2010). Drainages of supraglacial lakes can also establish links between the surface and the bed, decreasing basal friction and increasing short-term ice velocities (Box and Ski, 2007; Das et al., 2008; Schoof, 2010). Dynamic changes on land-terminating ice have been attributed to bedrock lubrication from increased meltwater (Zwally et al., 2002; Sundal et al., 2009; Bartholomew et al., 2010), and while marine-terminating glaciers additionally experience destabilized calving fronts (Thomas et al., 2003; Amundson et al., 2008) and enhanced ice-bottom melting from warm ocean waters (Holland et al., 2008; Straneo et al., 2010; Yin et al., 2011), surface melt is a primary link to increased basal sliding through changes in subglacial conduits (Colgan et al., 2011; Sole et al., 2011).

A prime obstacle to quantifying and incorporating runoff processes into models of ice sheet dynamics is a scarcity of direct observations of meltwater exiting the ice sheet, both in rivers draining the ice sheet and from beneath marineterminating glaciers (Rignot and Steffen, 2008). Therefore, the amount of meltwater that truly reaches the ocean (rather than refreezing or being retained by the ice sheet) is presently unknown. Meltwater production on the ice sheet surface can be modeled from climate data (Box et al., 2006; Fettweis, 2007; Ettema et al., 2009), or observed using remote sensing (Abdalati and Steffen, 1997; Smith et al., 2003; Tedesco, 2007; Hall et al., 2008). However, its release from the ice sheet edge to the ocean remains largely unstudied. Existing research consists of a handful of modeling efforts (Bøggild et al., 1999; Lewis and Smith, 2009; Mernild et al., 2010, 2011) and site-specific field studies (Rasch et al., 2000; Stott and Grove, 2001; Chu et al., 2009; Mernild and Hasholt, 2009; McGrath et al., 2010).

Buoyant sediment plumes that develop in fjords downstream of outlet glaciers and rivers offer a link between ice sheet hydrology and the ocean that can plausibly be observed using satellite remote sensing (Chu et al., 2009; McGrath et al., 2010). Sediment is produced by abrasion as ice moves over underlying bedrock and is subsequently transported by meltwater, with sediment output affected by glaciological variables such as glacier size, sliding speed, ice flux, and meltwater production, as well as erosional susceptibility of the bedrock (Hallet et al., 1996). Plumes are formed when sediment-rich freshwater runoff from the ice sheet enters the fjord - either directly, for marine-terminating glaciers, or via rivers, for land-terminating glaciers - and floats over denser saline marine water. As meltwater enters the fjord, a buoyant plume typically develops provided sediment concentrations do not exceed $\sim 40000 \mathrm{mg} \mathrm{l}^{-1}$ (Mulder and Syvitski, 1995). These features are readily observed in satellite imagery, allowing remote estimation of water-quality characteristics including suspended sediment concentration (SSC; e.g. Curran and Novo, 1988; Doxaran et al., 2002; Hu et al., 2004; Miller and McKee, 2004). The area and length of buoyant plumes have also been measured as a proxy for hydrologic outflows from the land surface to ocean (e.g. Thomas and Weatherbee, 2006; Halverson and Pawlowicz, 2008; Lihan et al., 2008; Chu et al., 2009; McGrath et al., 2010).

In the upper fjord environment where rivers first enter the coastal zone, plume spreading and mixing are driven predominantly by the kinetic energy of river discharge (Syvitski et al., 1985), but plume characteristics are still controlled by a complex combination of factors both on land and after entering the fjord. Sediment-rich meltwater from land-terminating outlet glaciers may encounter lakes, outwash plains, or braided river valleys, all of which can act as traps or sources for sediment (Busskamp and Hasholt, 1996; Hasholt, 1996); these land-terminating fjords tend to be dominated by surface meltwater (Dowdeswell and Cromack, 1991). While sediment transport in rivers from landterminating glaciers have been commonly studied through a relationship between river discharge and suspended sediment concentration (SSC) or total sediment load, some hysteresis has been found, where limitations in sediment supply result in decreased SSC despite increased meltwater runoff (Hammer and Smith, 1983; Schneider and Bronge, 1996; Willis et al., 1996). For marine-terminating outlet glaciers, sediment export to the ocean is dominated by the distinctly different mechanisms of iceberg rafting and/or en- and sub-glacially transported meltwater runoff (Andrews et al., 1994). In both environments, as plumes move farther downstream, sediment distribution and settling rates are further influenced by tides (Castaing and Allen, 1981; Bowers et al., 1998; Halverson and Pawlowicz, 2008), wind (Stumpf et al., 1993; Whitney and Garvine, 2005), and sea ice (Hasholt, 1996).

Here, buoyant sediment plumes that develop in upper fjord environments immediately downstream $(\sim 15-20 \mathrm{~km}$, with a maximum of $50 \mathrm{~km}$ ) of outlet glaciers and rivers that drain the Greenland ice sheet are mapped and analyzed using optical satellite imagery, to identify the distribution and temporal characteristics of sediment and meltwater release to coastal waters. Of particular interest is how well observed spatial and temporal variations in SSC respond to meltwater production on the ice sheet, and to what extent outlet glacier environments complicate this relationship, given that sediment supply hysteresis may also play a factor. SSC is used instead of plume area or length (Chu et al., 2009; McGrath et al., 2010) in order to expand the method beyond a river mouth. Optical images from the Moderate Resolution Imaging Spectroradiometer (MODIS) satellite are used from 2000-2009 to sample buoyant plume SSC in 230 fjords 
with data aggregation producing near-daily temporal resolution with $100 \mathrm{~km} \times 100 \mathrm{~km}$ coastal gridcells. These observations are then compared with a proxy for ice sheet surface melting (Polar MM5 modeled positive degree-days, PDD), routed through potential drainage basins derived from ice surface and bedrock topography (Lewis and Smith, 2009), as well as outlet glacier types. The end result is a synoptic, ten-year analysis of spatiotemporal plume behavior around Greenland and a first assessment of some important controls on their distribution and development.

\section{Data and methods}

To explore controls on sediment plume development, we considered (1) daily ice sheet surface melt using modeled PDD, routed into the fjords following potential drainage basins; (2) near-daily fjord SSC from calibrated MODIS satellite imagery aggregated into $100 \mathrm{~km}$ coastal gridcells; and (3) outlet glacier environments. Each of these steps is described in the following Sects. 2.1-2.3 next.

\subsection{Ice sheet surface melt}

A key driver of sediment plume behavior explored here is ice sheet hydrology as represented by production of meltwater on the ice sheet surface. The fifth generation Polar Mesoscale Model (PMM5) provides a gridded $24 \mathrm{~km}$ resolution output of 3-hourly temperatures across the ice sheet surface from 2000-2009 (Box et al., 2006). Data were provided in a polar stereographic projection and a mask was applied to extract temperature data over the ice sheet. From these data, time series of daily positive degree-days were extracted by averaging the three-hourly temperatures greater than $0{ }^{\circ} \mathrm{C}$ for each day. PDD is a traditional measure of melt intensity based on relating the cumulative depth of ice and snow melt to the sum of positive air temperatures over a specified time interval, usually a day. It is widely used because of its simplicity in temperature-based melt-index models (Ohmura, 2001; Hock, 2003), which are viable alternatives to more sophisticated energy balance models (Bougamont et al., 2007). Here, PDDs are used untransformed as a broad-scale, simple proxy for meltwater production. While not a true approximation for meltwater runoff, PDDs have been used in previous studies to represent melt intensity (Smith et al., 2003) and have been compared to ice sheet hydrologic processes such as supraglacial lake drainage and river discharge (Georgiou et al., 2009; Mernild and Hasholt, 2009)

As a proxy for meltwater volume produced within each hydrologic drainage basin, the aforementioned PDD data were totaled over topographically determined basins and assumed to drain only to corresponding ice sheet outlet glaciers and rivers at the ice sheet edge.

The drainage basins, each unique to a $100 \mathrm{~km}$ coastal gridcell (for fjord sediment detection, described in Sect. 2.2.3) were defined using a previously derived vector dataset of ice sheet drainage basins based on potentiometric flow networks (Lewis and Smith, 2009), modeled from a combination of bedrock topography and surface topography by assuming hydrostatic pressure conditions and no conduit flows within the ice sheet. Basins were aggregated as necessary to correspond to each $100 \mathrm{~km}$ coastal gridcell, with final drainage basin area, $B$, and ice edge length, $I$, defined as the total horizontal length of the ice sheet edge bounded within each drainage basin. Melt area, $A_{\mathrm{PDD}}$, was calculated for each drainage basin by totaling the number of $24 \mathrm{~km}$ pixels with a daily PDD greater than $0{ }^{\circ} \mathrm{C}$. The fraction of drainage basin experiencing active melting, $F_{\mathrm{PDD}}$, was defined as melt area divided by drainage basin size $\left(F_{\mathrm{PDD}}=\frac{A_{\mathrm{PDD}}}{B}\right)$. Melt penetration distance, $D_{\mathrm{PDD}}=\frac{A_{\mathrm{PDD}}}{I}$, represented the average inland distance from the ice edge that experienced surface melting.

\subsection{Remote sensing of sediment plumes}

Methodology for MODIS remote sensing of sediment plumes is shown in the Fig. 1 flowchart. SSC was estimated by (1) classifying $10 \mathrm{yr}$ of available daily MODIS imagery into ice-free "open water" (ranging from clear water to sediment-rich water) areas in the fjords, (2) aggregating the $500 \mathrm{~m}$ data into $100 \mathrm{~km}$ gridcells to retain a high frequency temporal sampling, and (3) transform MODIS reflectance into SSC using an empirical relationship developed from field water samples to transform reflectance into SSC.

\subsubsection{MODIS $500 \mathrm{~m}$ satellite imagery and quality}

The MODIS instrument on NASA's Terra satellite acquired daily coverage over Greenland from 2000-2010 with seven bands in the visible and infrared spectra at $500 \mathrm{~m}$ spatial resolution and two bands at $250 \mathrm{~m}$ resolution. Time series of MODIS Level $2500 \mathrm{~m}$ surface reflectance product (MOD09) (Vermote et al., 2002), atmospherically corrected for gases, aerosols, and thin cirrus clouds, was used for the melt season (1 May-30 September) each year. These Level 2 data are aggregated into a daily product and available as tiles in a sinusoidal grid projection. Seven MODIS tiles were needed to cover all of Greenland (Fig. 2). MODIS data are freely available and were downloaded from the NASA Warehouse Inventory Search Tool (https://wist.echo.nasa.gov/api/). Note that while MODIS data were available for 2010, PMM5 PDD data were only available until 2009. Therefore, MODIS data were processed and displayed for 2010 but not included in $10 \mathrm{yr}$ averages for comparison with PDD.

Only high-quality "clear-sky" MODIS pixels were used from each daily MODIS image. High-quality clear-sky pixels were defined as having: (1) a near-nadir view with adequate solar illumination (i.e. satellite overpass between 1300 and 1700 UTC), (2) minimal cloud cover ("clear" cloud state from the MODIS internal cloud state quality flag), and (3) minimal atmospheric interference ("corrected product 


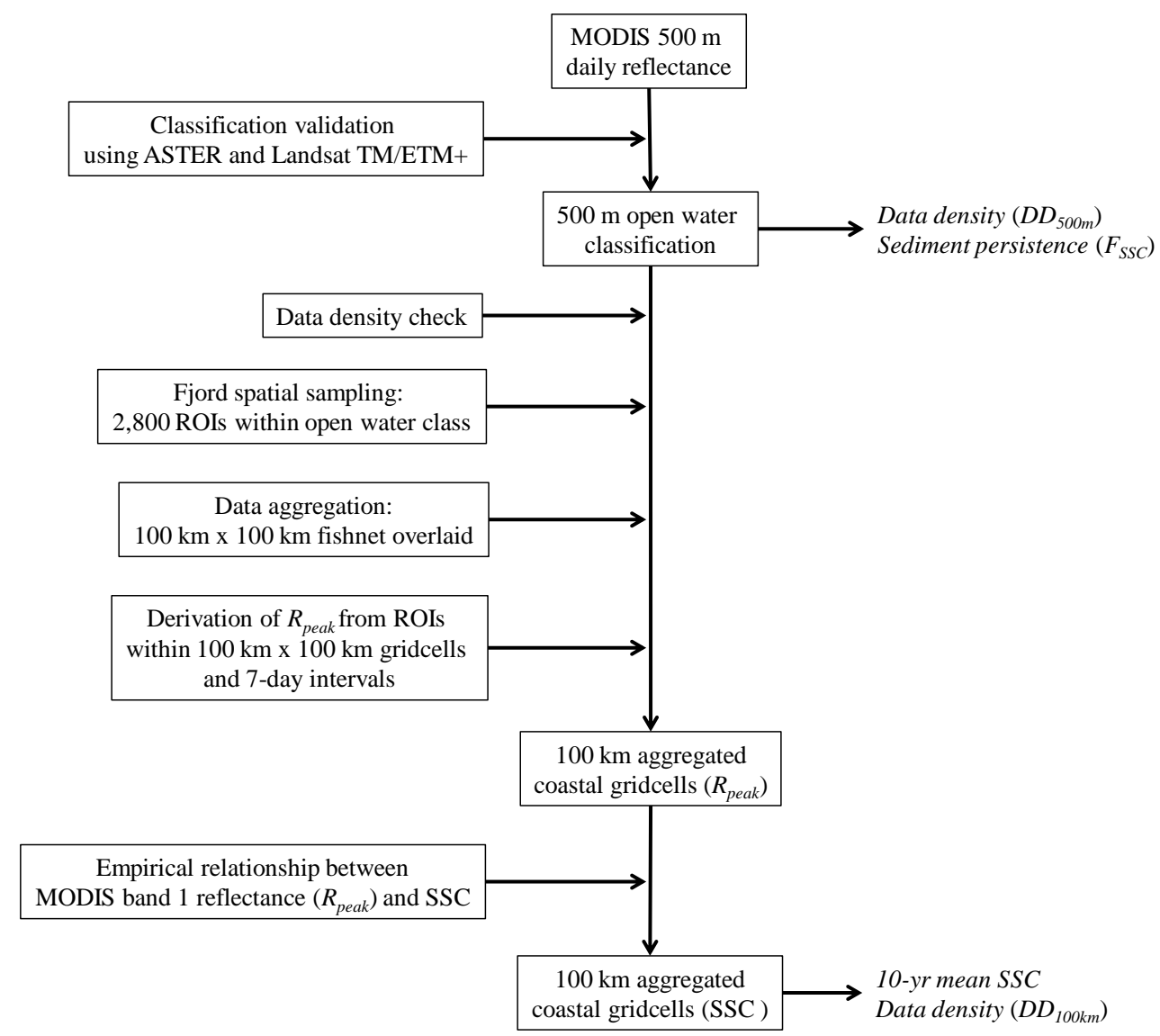

Fig. 1. Methodology flowchart of MODIS remote sensing of sediment plumes. Daily $500 \mathrm{~m}$ MODIS reflectance data were classified to identify open water pixels ranging from clear water to sediment-rich water, spatially validated using higher-resolution ASTER and Landsat TM/ETM+. Resulting $500 \mathrm{~m}$ open water classification produced measures of sediment persistence and data density. To increase temporal sampling, data were aggregated into $100 \mathrm{~km}$ coastal gridcells, whose value was represented by $R_{\text {peak }}$ within the gridcell and a 7-day interval. $R_{\text {peak }}$ was derived from fjord ROIs that met a data density threshold. SSC was extracted for each $100 \mathrm{~km}$ coastal gridcell using an empirical model relating MODIS band 1 reflectance $\left(R_{\text {peak }}\right)$ and SSC (Fig. 4). New measures of sediment persistence and data density along with average SSC were calculated from these data.

produced at ideal quality all bands" from the MODIS Land Assessment quality flags). These quality parameters were determined using MODIS $500 \mathrm{~m}$ (solar zenith data) and $1 \mathrm{~km}$ resolution (cloud state and atmospheric data) Quality Assurance (QA) datasets that provided quality flags for each band.

\subsubsection{Classification and validation of "open water"}

"Open water" pixels were defined as high quality MODIS pixels ranging from clear water to sediment-rich water, free of both clouds and ice, and distinguished using reflectance thresholds. MODIS band $1(620-670 \mathrm{~nm})$, band 2 (841$876 \mathrm{~nm})$, band $3(459-479 \mathrm{~nm})$, band $4(545-565 \mathrm{~nm})$, and band $6(1628-1652 \mathrm{~nm})$ were used with thresholds in a simplified classification scheme to mask out land, ice (including land-fast ice, sea ice, and calving icebergs), and clouds. Particular difficulty in distinguishing sediment-rich water from melting ice was due to similar spectral responses in the seven available MODIS bands, so thresholds were chosen conservatively to err on the side of missing sediment-rich water rather than over-sampling open water. Land and river pixels were identified primarily by a lower reflectance in band 2 than band 1. To distinguish clouds and ice, both of which show high reflectance in the visible bands, band 6 was used. Clouds were identified with band 6 reflectance $\gg$ band 1 reflectance. Remaining pixels with lower band 6 values were classified into ice (hereafter this class will include brash ice, patchy sea ice, icebergs, and melting states of the above) and open water. Ice was distinguished with band 2 reflectance greater than $0.5^{*}$ band 1 reflectance. Finally, open water $(\mathrm{OW})$ was then produced as a range of clear water to sediment-rich water free of clouds and ice.

The "open water" pixel classification was verified manually and statistically using 10 ASTER Level $215 \mathrm{~m}$ 
surface reflectance (AST 07) images and 27 Landsat TM/ETM $+30 \mathrm{~m}$ images (Fig. 2). Scenes for both sensors were limited to those during the summer melt season where plumes could be expected as well as in areas representing contrasting outlet glacier types and different spatial locations along the coast of Greenland. Melting ice, again including brash ice, patchy sea ice, and icebergs from calving glaciers, proved difficult to discern in the MODIS data due to its similarity with sediment-rich water, caused by low resolution spatially and spectrally with just seven available bands at $500 \mathrm{~m}$ resolution. This distinction of open water, which includes sediment-rich water, was crucial due to this class being used to extract SSC. The various ice states were more discrete in ASTER and Landsat, allowing the higher resolution images to act as validation classifications, testing whether the restrictive MODIS thresholds used for extracting open water were adequate. Accuracy was determined by performing a supervised classification on the higher resolution images and comparing them to the MODIS classification, with the class of quality-flagged pixels from MODIS masked out due to lack of comparable class in the higher resolution imagery. As shown in the results, a high overall accuracy and particularly a high user accuracy for the open water class showed the classification to be a conservative estimate of open water and adequate for estimation of SSC.

Data density and sediment persistence were calculated for each $500 \mathrm{~m}$ MODIS pixel from the classified open water data to characterize the frequency of data recovery and high sediment concentration. Data density, $\mathrm{DD}_{500 \mathrm{~m}}$, was defined as the percentage of non-ice, non-cloud open water days over the entire period, and ranges from 0 (no open water) to $100 \%$ (open water detected every day).

While open water is the primary classification used in further analysis, a sediment persistence metric, $F_{\mathrm{SSC}}$, was used to distinguish high SSC from low SSC to understand the temporal aspects of highly concentrated sediment lingering in the fjords. The threshold of band $1>0.12$ developed in Chu et al. (2009) was used for identifying the highest sediment concentrations, designated the "plume" as opposed to the "brackish plume" in the sediment-rich Kangerlussuaq Fjord, so the same threshold used all around Greenland should identify only the highest SSCs and provide a conservative estimate of persistence. Sediment persistence was defined as the fraction of high-SSC days $\left(\mathrm{OW}_{\mathrm{SSC}}\right)$ out of OW.

\subsubsection{MODIS spatial sampling and aggregation}

Fjord spatial sampling using 2800 regions of interest (ROIs) covering $7500 \mathrm{~km}^{2}$ over 230 fjords were manually delineated to enable MODIS sampling of all fjords directly draining the ice sheet via land-terminating and marine-terminating glaciers (Fig. 3). This restriction of analysis to fjords immediately draining the ice sheet reduced sampling of plumes triggered by melting snow packs, coastal erosion, and other sedimentary processes not necessarily triggered by ice sheet

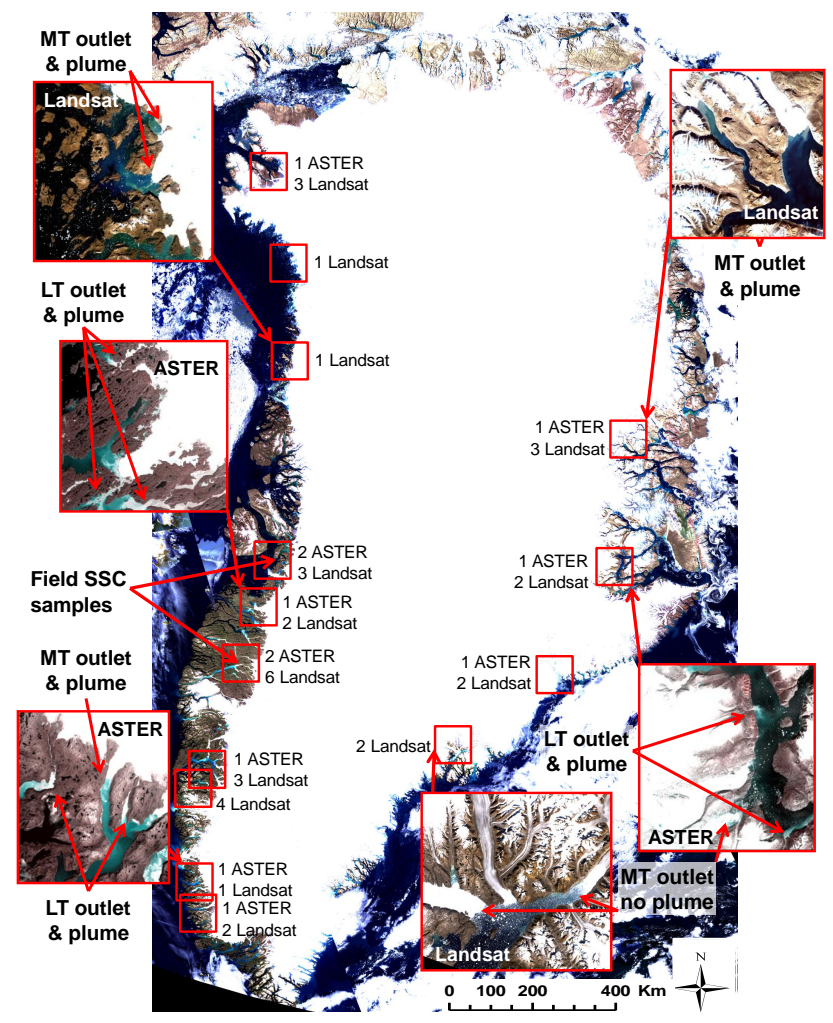

Fig. 2. MODIS mosaic of Greenland $(\mathrm{RGB}=$ bands $1,4,3)$ with Landsat $\mathrm{TM} / \mathrm{ETM}+(\mathrm{RGB}=$ bands $3,2,1)$ and ASTER (RGB = bands $2,1,1)$ image locations used for classification validation. Remote sensing analysis included all fjords directly draining the ice sheet through land-terminating glaciers (and downstream rivers) or from marine-terminating glaciers where plumes may form. Landsat and ASTER images show examples of different outlets and resulting plumes, including: (1) fjords fed by land-terminating glaciers, with large sediment plumes forming after transport through a river (LT outlet and plume) (2) fjords with marine-terminating glaciers (MT outlet and plume), few icebergs and a visible plume, and (3) fjords with marine-terminating glaciers heavily calving ice and no visible plume (MT outlet no plume).

meltwater runoff. ROIs were typically digitized within $\sim 15-$ $20 \mathrm{~km}$ and not more than $50 \mathrm{~km}$ of river mouths and outlet glacier termini, rather than further down-fjord or in the open ocean.

To reduce the loss of open water data from clouds and obtain more precise temporal sampling, the $500 \mathrm{~m}$ nativeresolution MODIS data, restricted to fjord ROIs, were aggregated into $100 \mathrm{~km} \times 100 \mathrm{~km}$ coastal gridcells to yield the final dataset for all further analyses (Fig. 3). First, a $100 \mathrm{~km}$ fishnet was overlaid onto the seven mosaicked MODIS tiles to summarize the SSC data within the ROIs. MODIS tiles were reprojected from the original sinusoidal projection to match the PMM5 model output polar sinusoidal projection. For each $100 \mathrm{~km}$ gridcell, $R_{\text {peak }}$ was determined from the population of data within the ROIs. $R_{\text {peak }}$ was defined as the 
median of the top 20 OW MODIS band 1 reflectance values (based on empirical model described in Sect. 2.2.4) to avoid biases from ROI placement or number of ROIs per $100 \mathrm{~km}$ gridcell. Furthermore, to help mitigate the effects of data loss from cloud and ice interference, a 7-day moving interval was applied over the raw data in conjunction with the spatial resampling, effectively allowing the resulting daily value to derive from a sample population anywhere within the ROIs in each $100 \mathrm{~km}$ gridcell, and anywhere from three days before to three days after the day of interest. While this assumes that a sample from a partially cloudy $100 \mathrm{~km}$ gridcell is equivalent to a cloud-free box, $R_{\text {peak }}$ represents the average plume state within a week, allowing a week for the best pixels to be sampled.

\subsubsection{Calibration/validation of SSC}

The final data product of daily $R_{\text {peak }}$ aggregated into $100 \mathrm{~km}$ coastal gridcells was transformed into SSC using an empirical relationship between remotely sensed reflectance and in situ measurements of SSC.

Field samples of SSC were necessary to understand plume characteristics, how SSC relates to the presence of freshwater, and how varying levels of sediment affect the spectral reflectance of the water. In situ water quality data were collected 3 June 2008 in Kangerlussuaq Fjord, southwest Greenland, with surface measurements of SSC, salinity, spectral reflectance, optical depth, and temperature collected every $1 \mathrm{~km}$ along a $22 \mathrm{~km}$ transect as described in Chu et al. (2009). Additional surface water samples (providing only laboratory measurements of SSC) from Eqip Sermia, a marine-terminating fjord in western Greenland, were collected 4 July 2007 and points were selected if they overlapped with digitized ROIs near the coast where buoyant sediment plumes were found, yielding three locations around $69.79^{\circ} \mathrm{N}, 50.53^{\circ} \mathrm{W}$ (Fig. 2). These additional measurements supplemented the more extensive Kangerlussuaq Fjord dataset by providing in situ SSCs from an environment dominated by marine-terminating glaciers. An empirical model relating SSC to MODIS reflectance (Fig. 4) was constructed using all available field samples and simultaneous MODIS band $1(620-670 \mathrm{~nm})$ reflectance as per Chu et al. (2009), yielding a new revised model of:

$R($ band 1$)=3.02 \ln (\mathrm{SSC})+1.12$

$R^{2}=0.86, p<0.001$

with $R$ (band 1) as the reflectance (\%) for MODIS band 1 $(620-670 \mathrm{~nm})$ and SSC measured in $\mathrm{mgl}^{-1}$. The model shows reflectance very sensitive to lower SSCs but saturation at high SSCs beyond $100 \mathrm{mg}^{-1}$.

A new data density measurement, $\mathrm{DD}_{100 \mathrm{~km}}$, was calculated from the aggregated data, and a threshold of $\mathrm{DD}_{100 \mathrm{~km}}>45 \%$ was applied to produce the final gridcells used for further analysis.

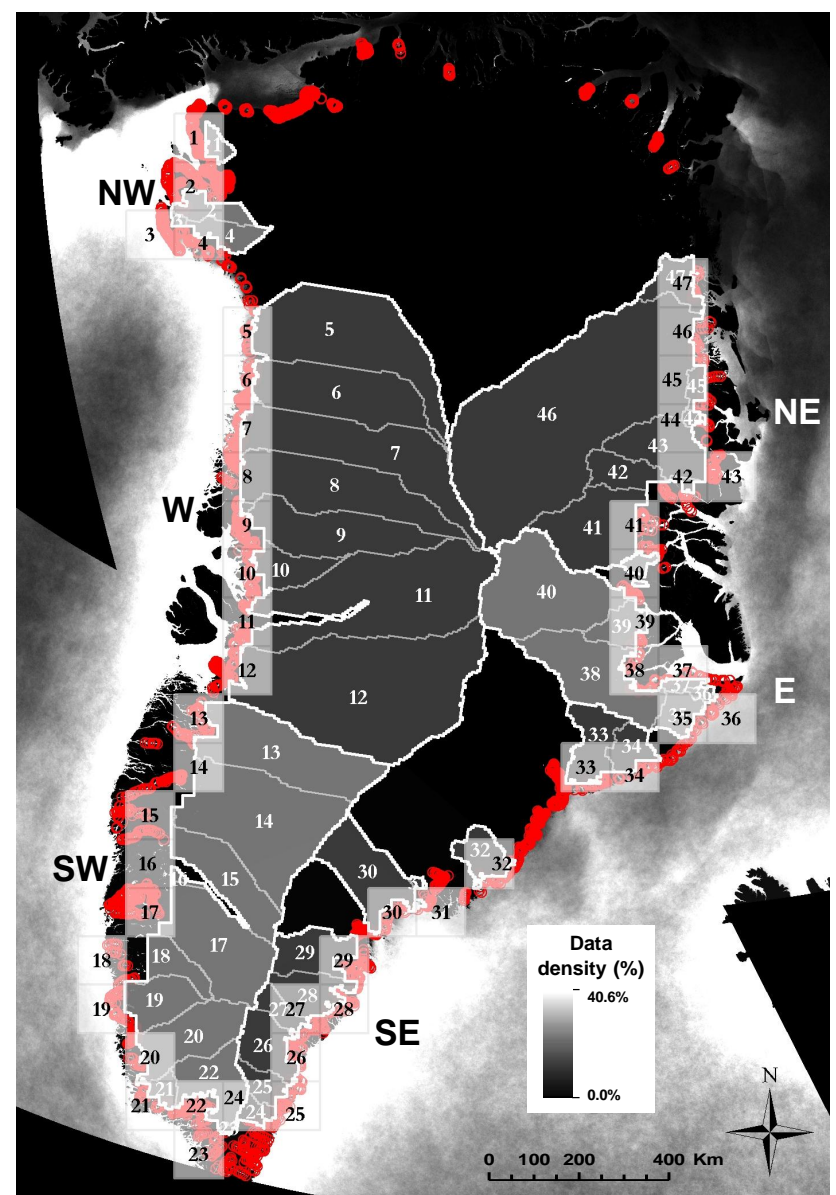

Fig. 3. Coastal $100 \mathrm{~km}$ gridcells and their corresponding ice sheet drainage basins are overlaid onto an image showing data density $\left(D_{500 \mathrm{~m}}\right.$ ) for $10 \mathrm{yr}$ of MODIS $500 \mathrm{~m}$ data, representing the number of open water days classified for each pixel out of a total of 1531 available and ranging from $0-40.6 \%$. Regions of interest (ROIs, red circles) are manually drawn to restrict open water data to fjords draining the ice sheet. Gridcells are grouped into six regions for summary analysis: Northwest (NW), West (W), Southwest (SW), Southeast (SE), East (E), and Northeast (NE). The north/northeast and a swath along the southeast contain very low frequencies of detected open water days due to the presence of sea ice and glaciers heavily calving icebergs.

\subsection{Outlet glacier environment}

Outlet glacier environments provide insight into the physical mechanisms by which sediment is dispersed from glacier outlets to fjords. While sediment transport in rivers (e.g. Hasholt, 1996; Rasch et al., 2000; Knudsen et al., 2007; Russell, 2007; Hasholt and Mernild, 2008) and sediment deposition in fjords (e.g. Syvitski et al., 1996; Reeh et al., 1999; Mugford and Dowdeswell, 2010) have previously been studied in Greenland, the active sediment plumes themselves are less studied (Chu et al., 2009; Lund-Hansen et al., 2010; McGrath et al., 2010). Though glacial erosion is responsible for 


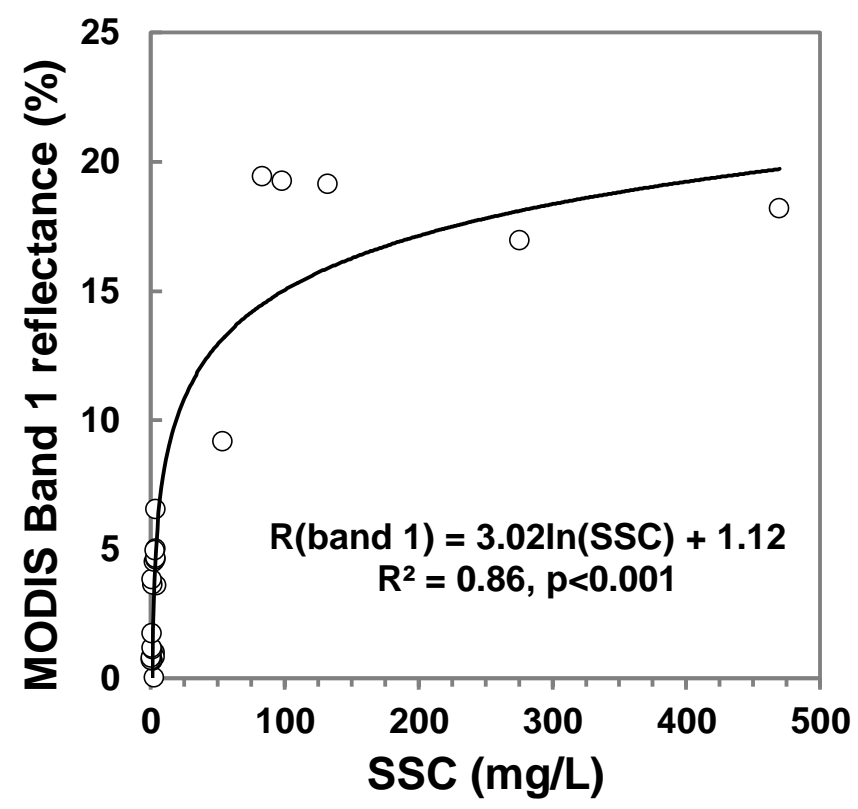

Fig. 4. Empirical relationship between field SSC and simultaneous MODIS band 1 reflectance, with 22 samples from Kangerlussuaq Fjord, a land-terminating glacier outlet, and 3 samples from Equip Sermia, a marine-terminating glacier outlet $\left(R^{2}=0.86, p<0.001\right)$.

some of the largest sediment yields to the ocean (Gurnell et al., 1996; Hallet et al., 1996), this paper focuses specifically on the fine glacial sediments transported by meltwater which remain in suspension in coastal waters, rather than total sediment flux and/or deposition processes.

The effect of outlet glacier environments on sediment concentrations was determined by characterizing outlet glacier type (marine- or land-terminating). Lewis and Smith (2009) provide georeferenced locations of all confirmed glacier meltwater outlets (i.e. land-terminating glaciers ending in rivers or lakes or marine-terminating glaciers with the presence of a sediment plume) and all unconfirmed glacier meltwater outlets (i.e. marine-terminating glaciers with no visible plume). These outlet types were further generalized into marine-terminating and land-terminating glacier outlets, and only those that fed into a corresponding $100 \mathrm{~km}$ coastal gridcell fjord area were counted and summarized within the gridcell. Marine-terminating outlets ranged from those with visible plumes and minimal iceberg activity to those heavily calving icebergs forming a "sikussak" complex of fused icebergs and sea ice attached to the glacier terminus (Syvitski, 1996). The ASTER/Landsat remote sensing validation process also proved useful for identifying gridcells dominated by fjords with heavily calving marine-terminating glaciers and no visible plume. Land-terminating outlets release meltwater at the ice sheet margin through proglacial lakes or rivers, and only those that eventually transport meltwater to the fjord through rivers or floodplains were included here.
The number of land-terminating outlets $\left(N_{\mathrm{L}}\right)$ and number of marine-terminating outlets $\left(N_{\mathrm{M}}\right)$ for each drainage basin were determined using the outlets in Lewis and Smith (2009). The counts were normalized by the total number of outlets to compute fractions of land-terminating glaciers $\left(F_{\mathrm{L}}\right)$ and marine-terminating glaciers $\left(F_{\mathrm{M}}\right)$.

\section{Results}

MODIS-derived estimates of coastal fjord SSC ranging from $\sim 0.7$ to $1925 \mathrm{mg} \mathrm{l}^{-1}$ were retrieved all around the ice sheet except in northern Greenland where persistent sea ice precludes detection of open water (Fig. 5, Table 1). PMM5derived PDD totals for ice sheet hydrologic basins draining to $100 \mathrm{~km}$ coastal gridcells, range from 0 to $165^{\circ} \mathrm{C}$ per day. Highest intensity is found along the ice sheet edge, decreasing exponentially farther inland with increasing elevations (Fig. 5, Table 1). Table 1 displays $10 \mathrm{yr}$ mean values for each parameter and each coastal gridcell/drainage basin pair. Basin mean melt area $\left(A_{\mathrm{PDD}}\right)$ ranges from $32-$ $16277 \mathrm{~km}^{2}$, with mean melt penetration distance $\left(D_{\mathrm{PDD}}\right)$ ranging from $0.3-112 \mathrm{~km}$ inland. Drainage basin size $(B)$ ranges from $553-142175 \mathrm{~km}^{2}$ with ice edge lengths $(I)$ varying between 35 and $344 \mathrm{~km}$. Adequate MODIS data density is found for 47 out of 83 coastal $100 \mathrm{~km}$ gridcells. The raw, native-resolution $500 \mathrm{~m}$ data show that on average a Greenland coastal ROI pixel experiences at most $26 \%$ of all days between 1 June and 30 September classified as open water (on average $14 \%$ ), that is, a water pixel without cloud or ice interference, from a total of 1531 days over the ten years $\left(\mathrm{DD}_{500 \mathrm{~m}}\right)$. On average the coastal gridcells contain 5 marine-terminating glacier outlets $\left(N_{\mathrm{M}}\right)$ and 4 land-terminating glacier outlets $\left(N_{\mathrm{L}}\right)$. Spatially and temporally aggregated $100 \mathrm{~km}$ gridcells for SSC show an improved data density, with a minimum threshold of $\mathrm{DD}_{100 \mathrm{~km}}>45 \%$ yielding the 47 gridcells for further analysis and a mean $\mathrm{DD}_{100 \mathrm{~km}}$ of $75 \% .10 \mathrm{yr}$ mean sediment persistence $\left(F_{\mathrm{SSC}}\right)$ averages 0.11 for the entire ice sheet, meaning gridcells show high-SSC values for one-tenth of the open water days detected on average.

The extraction of SSC through open water classification and extrapolation from an empirical model provides a broad measurement of sediment concentration around the ice sheet. The classification validation shows an overall accuracy of $79 \%$, and specifically for the open water class, reveals a producer accuracy of $66 \%$ and a user accuracy of $82 \%$. In other words, while only $66 \%$ of open water pixels (including sediment-rich water) have been correctly identified as open water, $82 \%$ of the pixels called open water are truly open water. This conservative estimate of open water areas was deemed adequate for estimation of SSC. The limited 25 field samples required SSC extrapolation beyond those known values in the model relating MODIS reflectance to SSC, resulting in $5.6 \%$ of extracted SSC values greater than 
Table 1. All parameters for each of the 47 gridcells, which are grouped and averaged into six regions. $10 \mathrm{yr}$ mean SSC \pm standard deviation $(s), 10 \mathrm{yr}$ median SSC, and $10 \mathrm{yr}$ mean PDD $\pm s$ are shown with standard deviations, and region averages are shown with standard deviations of gridcell averages within the region. $B$ is drainage basin size (with medians summarizing regions), $I$ is horizontal ice edge length, $A_{\mathrm{PDD}}$ is melt area within each drainage basin, $F_{\mathrm{PDD}}$ is percent of drainage basin actively melting, $D_{\mathrm{PDD}}$ is melt penetration distance, $N_{\mathrm{M}}$ is number of marine-terminating glacier outlets, $F_{\mathrm{M}}$ is the fraction of marine-terminating outlets, $N_{\mathrm{L}}$ is number of land-terminating glacier outlets, $F_{\mathrm{L}}$ is the fraction of land-terminating outlets, $\mathrm{DD}_{500 \mathrm{~m}}$ is average data density of open water from raw $500 \mathrm{~m}$ data, $\mathrm{DD}_{100 \mathrm{~km}}$ is data density of open water from aggregated $100 \mathrm{~km}$ gridcells, $F_{\mathrm{SSC}}$ is sediment persistence (fraction of high-SSC days from total open water days), $R$ (interannual) is the correlation between interannual variations of SSC and PDD over 2000-2009, and $R$ (seasonal) is the correlation between $10 \mathrm{yr}$ mean seasonal cycles, with significant correlations $(p<0.05)$ in bold.

\begin{tabular}{|c|c|c|c|c|c|c|c|c|c|c|c|c|c|c|c|c|c|}
\hline Gridcell & $\begin{array}{r}10 \mathrm{yr} \text { Mean SSC } \\
\pm s\left(\mathrm{mg}^{-1}\right)\end{array}$ & $\begin{array}{r}10 \mathrm{yr} \text { Median SSC } \\
\left(\mathrm{mg} \mathrm{l}^{-1}\right)\end{array}$ & $\begin{array}{r}10 \mathrm{yr} \text { Mean PDD } \\
\pm s\left({ }^{\circ} \mathrm{C}\right)\end{array}$ & $\begin{array}{r}B \\
\left(\mathrm{~km}^{2}\right)\end{array}$ & $\begin{array}{r}I \\
(\mathrm{~km})\end{array}$ & $\begin{array}{l}A_{\mathrm{PDD}} \\
\left(\mathrm{km}^{2}\right)\end{array}$ & $F_{\mathrm{PDD}}$ & $D_{\mathrm{PDD}}$ & $\begin{array}{r}N_{\mathrm{L}} \\
(\mathrm{km})\end{array}$ & $F_{\mathrm{L}}$ & $N_{\mathrm{M}}$ & $F_{\mathrm{M}}$ & $\begin{array}{r}\mathrm{DD}_{500 \mathrm{~m}} \\
(\%)\end{array}$ & $\begin{array}{r}\mathrm{DD}_{100 \mathrm{~km}} \\
(\%)\end{array}$ & $\begin{array}{r}F_{\text {SSC }} \\
(\%)\end{array}$ & $\begin{array}{r}R \\
\text { (Interann.) }\end{array}$ & $\begin{array}{r}R \\
\text { (Seasonal) }\end{array}$ \\
\hline 1 & $40 \pm 277$ & 5 & $1.23 \pm 3.78$ & 2847 & 141 & 830 & 0.29 & 5.9 & 3 & 0.33 & 6 & 0.67 & $22.2 \%$ & $92.2 \%$ & 0.14 & 0.61 & 0.48 \\
\hline 2 & $162 \pm 4$ & 42 & $2.23 \pm 2.03$ & 6,587 & 212 & 1720 & 0.26 & 8.1 & 10 & 0.71 & 4 & 0.29 & $14.4 \%$ & $85.6 \%$ & 0.16 & 0.26 & 0.75 \\
\hline 3 & $13 \pm 75$ & 2 & $0.78 \pm 1.20$ & 711 & 73 & 310 & 0.44 & 4.2 & 5 & 0.50 & 5 & 0.50 & $20.4 \%$ & $89.4 \%$ & 0.07 & 0.02 & 0.63 \\
\hline 4 & $4 \pm 35$ & 2 & $1.10 \pm 1.31$ & 6711 & 189 & 1041 & 0.16 & 5.5 & 1 & 0.07 & 14 & 0.93 & $8.4 \%$ & $75.1 \%$ & 0.09 & -0.18 & 0.46 \\
\hline Northwest & $55 \pm 63$ & 13 & $1.34 \pm 0.54$ & 4,214 & 154 & 975 & 0.29 & 5.9 & 5 & 0.40 & 7 & 0.60 & $16.4 \%$ & $85.6 \%$ & 0.11 & 0.18 & 0.58 \\
\hline 5 & 827 & 2 & 5.097 .07 & 55652 & 207 & 4531 & 0.08 & 21.9 & 0 & 0.00 & 6 & 1.00 & $5.4 \%$ & $57.7 \%$ & 0.09 & 0.17 & 0.54 \\
\hline 6 & $10 \pm 16$ & 3 & $3.81 \pm 4.92$ & 36968 & 212 & 3176 & 0.09 & 14.9 & 0 & 0.00 & 5 & 1.00 & $11.9 \%$ & $67.3 \%$ & 0.04 & 0.33 & 0.74 \\
\hline 7 & $42 \pm 95$ & 5 & $5.29 \pm 7.05$ & 46506 & 204 & 3645 & 0.08 & 17.8 & 3 & 0.27 & 8 & 0.73 & $13.7 \%$ & $81.6 \%$ & 0.06 & 0.58 & 0.87 \\
\hline 8 & $38 \pm 58$ & 26 & $7.86 \pm 9.82$ & 41373 & 121 & 4721 & 0.11 & 39.0 & 4 & 0.44 & 5 & 0.56 & $11.8 \%$ & $84.3 \%$ & 0.13 & 0.83 & 0.89 \\
\hline 9 & $18 \pm 26$ & 9 & $1.50 \pm 2.97$ & 30978 & 148 & 1,763 & 0.06 & 11.9 & 3 & 0.50 & 3 & 0.50 & $19.8 \%$ & $73.7 \%$ & 0.02 & 0.42 & 0.81 \\
\hline 10 & $140 \pm 290$ & 18 & $2.30 \pm 3.61$ & 10166 & 203 & 2089 & 0.21 & 10.3 & 0 & 0.00 & 4 & 1.00 & $19.3 \%$ & $78.8 \%$ & 0.04 & 0.83 & 0.55 \\
\hline 11 & $109 \pm 227$ & 17 & $7.74 \pm 9.42$ & 72190 & 170 & 5495 & 0.08 & 32.3 & 1 & 0.17 & 5 & 0.83 & $16.1 \%$ & $91.4 \%$ & 0.05 & 0.32 & 0.76 \\
\hline 12 & $93 \pm 220$ & 32 & $13.25 \pm 15.49$ & 99210 & 224 & 9863 & 0.10 & 44.1 & 3 & 0.43 & 4 & 0.57 & $16.5 \%$ & $79.9 \%$ & 0.10 & 0.46 & 0.08 \\
\hline West & $57 \pm 47$ & 14 & $5.85 \pm 3.82$ & 49131 & 186 & 4410 & 0.10 & 24.0 & 2 & 0.23 & 5 & 0.77 & $14.3 \%$ & $76.9 \%$ & 0.07 & 0.49 & 0.65 \\
\hline 13 & $112 \pm 119$ & 90 & $23.12 \pm 24.21$ & 39,964 & 258 & 10,551 & 0.26 & 40.9 & 13 & 0.87 & 2 & 0.13 & $22.6 \%$ & $94.4 \%$ & 0.19 & -0.09 & 0.62 \\
\hline 14 & $555 \pm 422$ & 521 & $30.79 \pm 34.27$ & 55891 & 146 & 16277 & 0.29 & 111.9 & 8 & 1.00 & 0 & 0.00 & $25.9 \%$ & $78.4 \%$ & 0.44 & -0.08 & 0.92 \\
\hline 15 & $238 \pm 209$ & 209 & $10.76 \pm 12.86$ & 21152 & 111 & 6,725 & 0.32 & 60.7 & 3 & 1.00 & 0 & 0.00 & $16.9 \%$ & $89.5 \%$ & 0.33 & -0.09 & 0.65 \\
\hline 16 & $207 \pm 187$ & 171 & $3.93 \pm 4.38$ & 1200 & 39 & 1200 & 1.00 & 30.9 & 2 & 1.00 & 0 & 0.00 & $23.9 \%$ & $91.3 \%$ & 0.33 & -0.23 & 0.61 \\
\hline 17 & $312 \pm 405$ & 130 & $11.10 \pm 12.83$ & 33462 & 135 & 7803 & 0.23 & 58.0 & 5 & 0.71 & 2 & 0.29 & $17.3 \%$ & $81.6 \%$ & 0.20 & 0.19 & 0.81 \\
\hline 18 & $552 \pm 481$ & 473 & $9.64 \pm 10.41$ & 8603 & 135 & 4314 & 0.50 & 31.8 & 3 & 0.75 & 1 & 0.25 & $14.4 \%$ & $84.9 \%$ & 0.21 & -0.25 & 0.82 \\
\hline 19 & $397 \pm 345$ & 365 & $13.39 \pm 13.85$ & 12796 & 159 & 4926 & 0.38 & 31.0 & 6 & 1.00 & 0 & 0.00 & $14.1 \%$ & $91.3 \%$ & 0.17 & -0.01 & 0.35 \\
\hline 20 & $129 \pm 213$ & 40 & $16.55 \pm 16.11$ & 21386 & 245 & 6272 & 0.29 & 25.6 & 3 & 0.50 & 3 & 0.50 & $9.9 \%$ & $87.1 \%$ & 0.09 & -0.21 & 0.81 \\
\hline 21 & $61 \pm 76$ & 37 & $5.53 \pm 4.86$ & 3134 & 131 & 1384 & 0.44 & 10.6 & 7 & 0.88 & 1 & 0.13 & $15.9 \%$ & $93.5 \%$ & 0.13 & -0.10 & 0.52 \\
\hline 22 & $250 \pm 351$ & 130 & $12.19 \pm 13.09$ & 15793 & 338 & 6219 & 0.39 & 18.4 & 12 & 0.57 & 9 & 0.43 & $15.0 \%$ & $94.4 \%$ & 0.12 & -0.45 & 0.31 \\
\hline 23 & $72 \pm 115$ & 16 & $0.96 \pm 0.96$ & 553 & 35 & 349 & 0.63 & 9.8 & 4 & 0.67 & 2 & 0.33 & $7.2 \%$ & $92.9 \%$ & 0.12 & -0.26 & 0.85 \\
\hline Southwest & $262 \pm 168$ & 198 & $12.54 \pm 8.16$ & 19449 & 157 & 6002 & 0.43 & 39.0 & 6 & 0.81 & 2 & 0.19 & $16.7 \%$ & $89.0 \%$ & 0.21 & -0.14 & 0.66 \\
\hline 24 & $6 \pm 13$ & 3 & $0.30 \pm 0.45$ & 3052 & 74 & 176 & 0.06 & 2.4 & 1 & 0.09 & 10 & 0.91 & $5.6 \%$ & $61.5 \%$ & 0.01 & 0.12 & 0.42 \\
\hline 25 & $4 \pm 6$ & 2 & $1.94 \pm 3.10$ & 5344 & 92 & 1196 & 0.22 & 13.1 & 0 & 0.00 & 12 & 1.00 & $7.8 \%$ & $68.9 \%$ & 0.01 & 0.04 & 0.28 \\
\hline 26 & $26 \pm 62$ & 3 & $1.05 \pm 2.10$ & 11994 & 227 & 891 & 0.07 & 3.9 & 3 & 0.18 & 14 & 0.82 & $5.6 \%$ & $99.9 \%$ & 0.01 & -0.39 & 0.46 \\
\hline 27 & $91 \pm 184$ & 31 & $0.27 \pm 0.60$ & 4808 & 125 & 227 & 0.05 & 1.8 & 0 & 0.00 & 4 & 1.00 & $9.0 \%$ & $68.5 \%$ & 0.10 & -0.32 & 0.32 \\
\hline 28 & $5 \pm 9$ & 3 & $1.27 \pm 2.35$ & 11,014 & 344 & 963 & 0.09 & 2.8 & 3 & 0.13 & 20 & 0.87 & $8.3 \%$ & $89.5 \%$ & 0.04 & -0.23 & 0.10 \\
\hline 29 & $3 \pm 5$ & 2 & $1.04 \pm 1.83$ & 13047 & 184 & 1026 & 0.08 & 5.6 & 0 & 0.00 & 15 & 1.00 & $5.0 \%$ & $82.0 \%$ & 0.01 & -0.37 & 0.09 \\
\hline 30 & $3 \pm 3$ & 2 & $2.14 \pm 3.42$ & 22,121 & 318 & 2590 & 0.12 & 8.2 & 2 & 0.15 & 11 & 0.85 & $7.7 \%$ & $78.4 \%$ & 0.08 & -0.01 & 0.64 \\
\hline 31 & $2 \pm 1$ & 2 & $0.30 \pm 0.42$ & 753 & 110 & 219 & 0.29 & 2.0 & 1 & 0.25 & 3 & 0.75 & $10.3 \%$ & $81.0 \%$ & 0.02 & 0.00 & 0.63 \\
\hline 32 & $44 \pm 90$ & 15 & $1.84 \pm 2.85$ & 8391 & 250 & 1542 & 0.18 & 6.2 & 1 & 0.05 & 19 & 0.95 & $7.1 \%$ & $67.1 \%$ & 0.12 & 0.20 & 0.40 \\
\hline 33 & $64 \pm 91$ & 33 & $1.78 \pm 2.97$ & 13117 & 302 & 1472 & 0.11 & 4.9 & 3 & 0.30 & 7 & 0.70 & $7.2 \%$ & $56.8 \%$ & 0.16 & 0.05 & 0.30 \\
\hline 34 & $49 \pm 103$ & 24 & $0.56 \pm 1.12$ & 6917 & 197 & 635 & 0.09 & 3.2 & 0 & 0.00 & 8 & 1.00 & $9.0 \%$ & $50.9 \%$ & 0.13 & 0.43 & 0.09 \\
\hline Southeast & $27 \pm 29$ & 11 & $1.13 \pm 0.68$ & 9142 & 202 & 994 & 0.12 & 4.9 & 1 & 0.10 & 11 & 0.90 & $7.5 \%$ & $73.1 \%$ & 0.06 & -0.04 & 0.34 \\
\hline 35 & $11 \pm 17$ & 4 & $1.51 \pm 2.72$ & 6235 & 126 & 1111 & 0.18 & 8.8 & 3 & 0.50 & 3 & 0.50 & $10.8 \%$ & $56.6 \%$ & 0.00 & 0.41 & 0.33 \\
\hline 36 & $4 \pm 3$ & 3 & $0.83 \pm 1.28$ & 1464 & 62 & 363 & 0.25 & 5.9 & 1 & 0.25 & 3 & 0.75 & $10.2 \%$ & $62.6 \%$ & 0.00 & -0.15 & 0.66 \\
\hline 37 & $23 \pm 31$ & 13 & $0.67 \pm 0.99$ & 1884 & 117 & 318 & 0.17 & 2.7 & 2 & 0.33 & 4 & 0.67 & $13.4 \%$ & $53.9 \%$ & 0.07 & 0.62 & 0.54 \\
\hline 38 & $26 \pm 28$ & 19 & $1.34 \pm 2.88$ & 29747 & 283 & 1462 & 0.05 & 5.2 & 9 & 0.64 & 5 & 0.36 & $12.2 \%$ & $65.6 \%$ & 0.04 & 0.68 & 0.44 \\
\hline 39 & $35 \pm 37$ & 21 & $0.42 \pm 0.95$ & 7563 & 170 & 302 & 0.04 & 1.8 & 7 & 0.58 & 5 & 0.42 & $20.9 \%$ & $65.1 \%$ & 0.08 & 0.17 & 0.55 \\
\hline 40 & $31 \pm 44$ & 14 & $0.45 \pm 1.01$ & 44694 & 310 & 490 & 0.01 & 1.6 & 6 & 0.67 & 3 & 0.33 & $6.8 \%$ & $63.4 \%$ & 0.09 & -0.11 & 0.72 \\
\hline East & $22 \pm 11$ & 12 & $0.87 \pm 0.42$ & 15264 & 178 & 674 & 0.12 & 4.3 & 5 & 0.50 & 4 & 0.50 & $12.4 \%$ & $61.2 \%$ & 0.05 & 0.27 & 0.54 \\
\hline 41 & $17 \pm 35$ & 4 & $0.91 \pm 2.19$ & 27790 & 242 & 841 & 0.03 & 3.5 & 6 & 0.60 & 4 & 0.40 & $19.0 \%$ & $65.4 \%$ & 0.04 & -0.25 & 0.66 \\
\hline 42 & $104 \pm 202$ & 38 & $0.47 \pm 1.03$ & 10232 & 178 & 501 & 0.05 & 2.8 & 3 & 0.60 & 2 & 0.40 & $22.9 \%$ & $65.6 \%$ & 0.08 & 0.46 & 0.57 \\
\hline 43 & $84 \pm 97$ & 53 & $1.13 \pm 2.49$ & 17528 & 170 & 1273 & 0.07 & 7.5 & 6 & 0.86 & 1 & 0.14 & $20.7 \%$ & $65.6 \%$ & 0.10 & 0.18 & 0.76 \\
\hline 44 & $13 \pm 35$ & 4 & $0.05 \pm 0.15$ & 1165 & 96 & 32 & 0.03 & 0.3 & 1 & 0.50 & 1 & 0.50 & $8.9 \%$ & $51.0 \%$ & 0.06 & -0.20 & 0.18 \\
\hline 45 & $21 \pm 31$ & 9 & $0.41 \pm 0.71$ & 2790 & 138 & 231 & 0.08 & 1.7 & 5 & 0.45 & 6 & 0.55 & $13.0 \%$ & $58.3 \%$ & 0.16 & 0.75 & 0.79 \\
\hline 46 & $115 \pm 141$ & 66 & $2.29 \pm 5.56$ & 142175 & 164 & 2675 & 0.02 & 16.3 & 2 & 0.50 & 2 & 0.50 & $14.1 \%$ & $53.7 \%$ & 0.27 & 0.32 & 0.30 \\
\hline 47 & $91 \pm 3$ & 74 & $0.50 \pm 4.15$ & 8043 & 180 & 437 & 0.05 & 2.4 & 3 & 0.60 & 2 & 0.40 & $17.9 \%$ & $45.4 \%$ & 0.11 & 0.61 & 0.49 \\
\hline Northeast & $63 \pm 41$ & 35 & $0.82 \pm 0.68$ & 29960 & 167 & 856 & 0.05 & 4.9 & 4 & 0.59 & 3 & 0.41 & $16.7 \%$ & $57.9 \%$ & 0.12 & 0.27 & 0.54 \\
\hline Gridcell Average & $94 \pm 121$ & 59 & $4.54 \pm 6.37$ & 21823 & 176 & 2685 & 0.19 & 16.2 & 4 & 0.44 & 5 & 0.56 & $13.5 \%$ & $74.7 \%$ & 0.11 & 0.13 & 0.54 \\
\hline Avg Gridcell Min & 2 & 2 & 0.05 & 553 & 35 & 32 & 0.01 & 0.3 & 0 & o & 0 & o & $5.0 \%$ & $45.4 \%$ & o & -0.45 & 0.08 \\
\hline Avg Gridcell Max & 555 & 521 & 30.79 & 142175 & 344 & 16277 & 1.00 & 111.9 & 13 & 1.00 & 20 & 1.00 & $25.9 \%$ & $99.9 \%$ & 0.44 & 0.83 & 0.92 \\
\hline
\end{tabular}


(a) 10-year mean

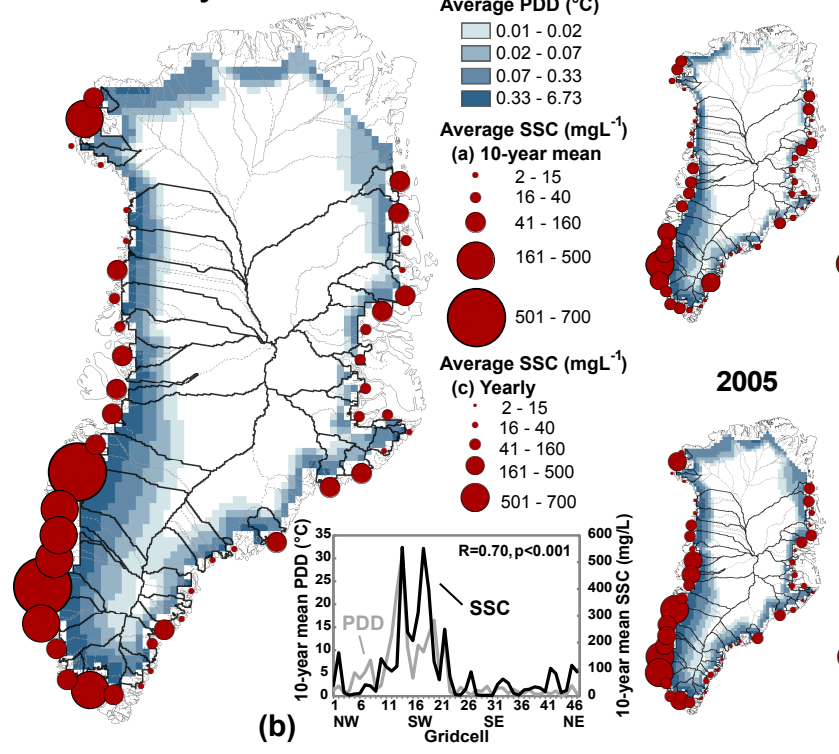

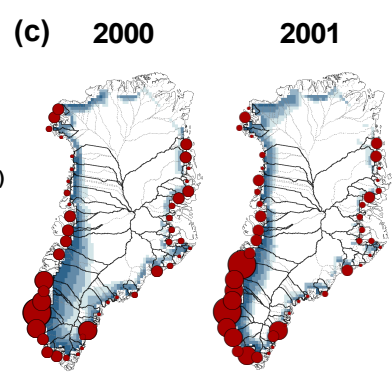
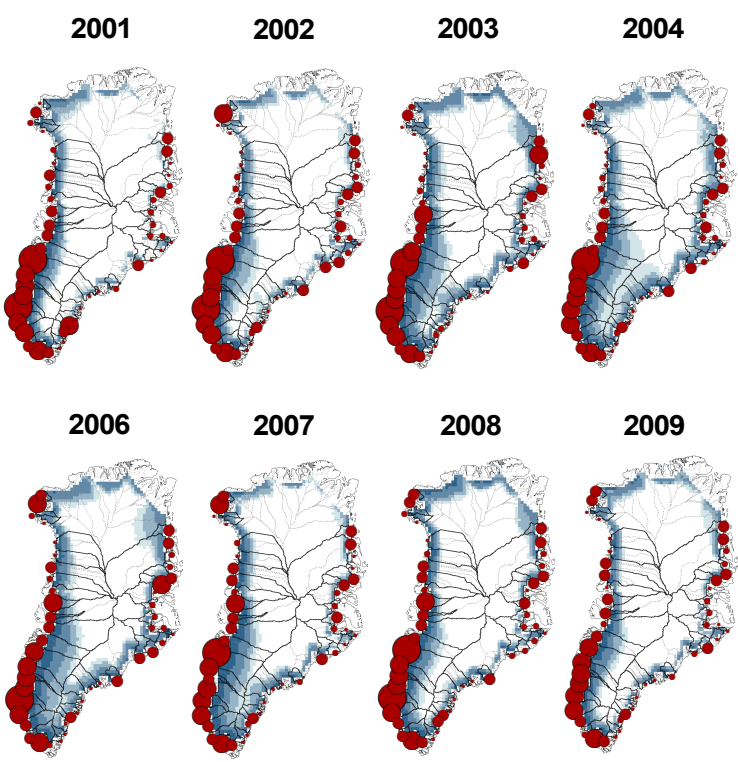

Fig. 5. (a) Map of $10 \mathrm{yr}$ mean ice sheet PDD (blue) and fjord plume SSC (red circles). (b) Spatial variation of 1 yr mean PDD (grey line) and SSC (black line), starting in the northwest and going counterclockwise towards the northeast $(R=0.70, p<0.001)$. (c) Map of mean yearly SSC (red circles) and PDD (blue) for 2000-2009.

the maximum field SSC. Comparative measurements of sediment concentration around Greenland only exist for either rivers, which show expected higher values (Hasholt, 1996), or for Kangerlussuaq Fjord, which shows a lower range of $1.5-367.7 \mathrm{mg}^{-1}$ for inorganic suspended particulate matter (Lund-Hansen et al., 2010). Given these limitations, analysis of SSC will rely on broad averages over temporal and spatial scales.

\subsection{Regional characteristics: mean SSC, mean PDD, data availability, and outlet glacier environment}

The aforementioned characteristics of Greenland as a whole mask strong regional differences around the edge of the ice sheet. In Table 1, the $100 \mathrm{~km}$ coastal gridcells are further aggregated into six regions: Northwest Region, West Region, Southwest Region, Southeast Region, East Region, and Northeast Region (Fig. 3). Note that results are presented with standard deviations $(s)$ for $10 \mathrm{yr}$ means to show variability within samples, and $10 \mathrm{yr}$ median SSC is also presented as another summary measure given the extrapolation of higher SSCs beyond field measurements.

The Northwest Region (Fig. 3) consists of four coastal gridcells (numbered 1-4) and exhibits a moderately low $10 \mathrm{yr}$ average SSC $\left(55 \pm 63 \mathrm{mgl}^{-1}\right.$, Table 1$)$, except for one uniquely high SSC gridcell (Gridcell 2), and a moderately low average PDD $\left(1.3 \pm 0.5^{\circ} \mathrm{C}\right)$. Gridcell 2 , off the coast west of Humboldt Glacier, has a mean SSC of $162 \pm 4 \mathrm{mg}^{-1}$, above average not only for the region but for the entire ice sheet as well and a high number of land-terminating glaciers $\left(N_{\mathrm{L}}=10\right)$. In contrast, Gridcell 4 directly to the south captures a high number of marineterminating glaciers $\left(N_{\mathrm{M}}=14\right)$ with a large swath of glaciers near to the coast, generating one of the lowest mean SSC values $\left(4 \mathrm{mg}^{-1}\right)$. This region has a high $\mathrm{DD}_{100 \mathrm{~km}}(86 \%)$ and a high $F_{\mathrm{SSC}}(0.11)$, meaning high concentrations of sediment are detected for one-tenth of the melt season, with many protected fjords and a relatively high average $N_{\mathrm{L}}$.

The West Region (Fig. 3) has eight coastal gridcells (numbered 5-12), including several large marine-terminating glaciers including Jakobshavn Isbrae (Gridcell 12), Store Glacier (Gridcell 11), and Rink Glacier (Gridcell 9). The West Region has a mean SSC of $57 \pm 47 \mathrm{mg} \mathrm{l}^{-1}$ (Table 1) similar to the Northwest Region, but a higher mean PDD $\left(5.9 \pm 3.8^{\circ} \mathrm{C}\right)$. This region contains high velocity marineterminating glaciers, with ones farther south characterized by floating or near-floating tongues (Thomas et al., 2009). This region has the largest average $B\left(49131 \mathrm{~km}^{2}\right)$ and contains Jakobshavn basin, the largest at a size of $99210 \mathrm{~km}^{2}$. A moderate $\mathrm{DD}_{100 \mathrm{~km}}(77 \%)$ and a moderately low $F_{\mathrm{SSC}}(0.07)$ reflect the mix of outlet and fjord types, with a low average $N_{\mathrm{L}}$ (2) and a moderate average $N_{\mathrm{M}}(5)$, but the highest fraction of marine-terminating glaciers $\left(F_{\mathrm{M}}=0.77\right)$.

The Southwest Region (Fig. 3) is made up of eleven coastal gridcells (numbered 13-23) and has the highest average values in most parameters: highest mean SSC (262 $\pm 168 \mathrm{mgl}^{-1}$, Table 1), highest mean PDD $\left(12.5 \pm 8.2^{\circ} \mathrm{C}\right)$, highest average $A_{\text {melt }}\left(6002 \mathrm{~km}^{2}\right)$, highest average $F_{\mathrm{SSC}}(0.21)$, highest average $N_{\mathrm{L}}$ as well as $F_{\mathrm{L}}$ 
(0.81), and the highest $\mathrm{DD}_{100 \mathrm{~km}}(89 \%)$. In particular, Gridcell 14, which encompasses Russell Glacier and the downstream Kangerlussuaq Fjord, shows the highest mean SSC $\left(555 \pm 422 \mathrm{mg} \mathrm{l}^{-1}\right)$ and by far the highest mean PDD $\left(30.8 \pm 34.3^{\circ} \mathrm{C}\right)$. The gently sloping coast and warmer climate contribute to the geomorphological uniqueness of this region. The extensive coastal land area affords every gridcell higher $F_{\mathrm{L}}$ than $F_{\mathrm{M}}$ and many large braided rivers to disperse the sediment into long, protected fjords. Going farther south in the region with less land area shows decreased mean SSC, decreased mean PDD, and decreased $F_{\text {SSC }}$.

The Southeast Region (Fig. 3) has eleven coastal gridcells (numbered 24-34), encompassing the same latitude range as the Southwest Region, and shows a marked difference from the Southwest with very low averages of SSC $\left(27 \pm 29 \mathrm{mg} \mathrm{l}^{-1}\right.$, Table 1), PDD $\left(1.1 \pm 0.7^{\circ} \mathrm{C}\right)$, and $F_{\mathrm{SSC}}$ (0.06). A moderate average $\mathrm{DD}_{100 \mathrm{~km}}(73 \%)$ despite loss of OW from icebergs reflects the removal of those gridcells that did not meet the data density threshold, particularly those encompassing the heavily calving Kangerdlugssuaq and Helheim Glaciers. Persistent sikussaks at the ends of these glaciers extend several kilometers and prevent any detection of OW. These glaciers also have very large drainage basins, so their removal is also indicated by the fairly small average $B\left(9142 \mathrm{~km}^{2}\right)$. In contrast with the southwest, the southeast has the highest average $N_{\mathrm{M}}\left(11\right.$, also highest $\left.F_{\mathrm{M}}=0.90\right)$ and lowest average $N_{\mathrm{L}}\left(1\right.$, also lowest $\left.F_{\mathrm{L}}=0.1\right)$. Most glaciers are near to the coast with steeper slopes and fairly low melting.

The East Region (Fig. 3) consists of six coastal gridcells (numbered 35-40) around the Scoresby Sund area and shows the lowest mean SSC (22 $\pm 11 \mathrm{mg} \mathrm{l}^{-1}$, Table 1) and one of the lowest mean PDDs $\left(0.9 \pm 0.4^{\circ} \mathrm{C}\right)$. Average $F_{\mathrm{SSC}}$ is also lowest of all regions (0.05), and two gridcells (Gridcells 35 and 36) do not show any sediment persistence, indicating that only very low concentrations of sediment exist in those areas. Average $\mathrm{DD}_{100 \mathrm{~km}}$ is one of the lowest $(61 \%)$, and outlets are fairly abundant in both marine-terminating and land-terminating types draining into protected fjords. The presence of a large land area as well as some islands allows for smaller glaciers and snowpatches not connected to the ice sheet to produce sediment, so ROIs were placed to avoid those areas as much as possible.

The Northeast Region (Fig. 3) has seven coastal gridcells (numbered 41-47). This region has the lowest average $\mathrm{DD}_{100 \mathrm{~km}}(58 \%)$, and the northernmost Gridcell 47 has the lowest individual gridcell $\mathrm{DD}_{100 \mathrm{~km}}(48 \%)$. The low $\mathrm{DD}_{100 \mathrm{~km}}$ of open water pixels free of ice is problematic in the northeast as well as in the northern areas; open water detection is prevented by the persistence of sea ice and/or iceberg calving. This region has the lowest mean $\mathrm{PDD}\left(0.8 \pm 0.7^{\circ} \mathrm{C}\right)$, but an intermediate mean SSC $\left(63 \pm 41 \mathrm{mg}^{-1}\right)$. Both land-terminating and marineterminating outlets are fairly low in number, with slightly more $N_{\mathrm{L}}$ (4) compared $N_{\mathrm{M}}(3)$.

\subsection{Hydrologic controls on fjord SSC: spatial, interannual, seasonal, and high frequency}

\subsubsection{Spatial variability}

A high spatial correlation between 2000-2009 PDD and SSC confirms that more ice sheet melting leads to more suspended sediment being mobilized by meltwater. Figure $5 \mathrm{~b}$ shows a strong correlation $(R=0.70, p<0.001)$ between the $10 \mathrm{yr}$ mean PDD and 10 ye r mean SSC moving counterclockwise around the ice sheet from the northwest to the northeast. Mean PDD and SSC for individual gridcells illustrate results from the grouped regions. The Northwest and West Regions show a slightly decoupled intensity between PDD and SSC, with Gridcell 2 in the Northwest experiencing a low average PDD but high average SSC, and Gridcells 5-8 in the West revealing higher average PDDs with lower average SSCs. The Southwest Region is distinct in high values of both, with a few gridcells (Gridcells 16-19) associated with high plume SSC's despite low ice sheet PDD. A distinct drop in both PDD and SSC denotes the movement from the western half of Greenland to the eastern half, which is characterized by overall lower average PDD and SSC intensities and less spatial variability in both datasets. Furthermore, PDD is a significant driver of SSC in high PDD areas but not in low PDD areas. Splitting the data in half with 24 high PDD gridcells and 23 low PDD gridcells, the high PDD portion show that PDD is strongly correlated with $\operatorname{SSC}(R=0.61, p=0.002)$, while the low PDD data are not correlated with SSC $(R=-0.16$, $p=0.47)$.

\subsubsection{Interannual variability}

Interannual variations between ice sheet PDD and plume SSC correlate for the West and Northeast regions, but lack significant correlations for the other regions (Northwest, East, Southwest, and Southeast) and for Greenland as a whole (Fig. 6). Nine gridcells that do show strong relationships are concentrated in the northern parts of Greenland; and for the most part the southern regions are not correlated interannually (Fig. 7d, Table 1). Gridcell 13 in the Southwest Region containing solely Kangerlussuaq Fjord where a strong positive interannual correlation was previously found between ice sheet melt area and sediment plume area (Chu et al., 2009) displays a slight anti-correlation, similar to most gridcells in the Southwest Region. This region highly influences the overall interannual relationship averaged Greenland owing to high values of both PDD and SSC.

\subsubsection{Seasonal variability}

Average seasonal climatologies of ice sheet PDD and downstream fjord SSC indicate coinciding seasonal cycles, with sediment plume onset coincident or commencing after surface melt onset (Fig. 8). Seasonal climatologies of PDD and SSC are produced by averaging across the same day-of-year 
(a)

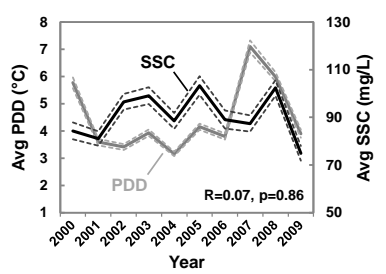

(b)
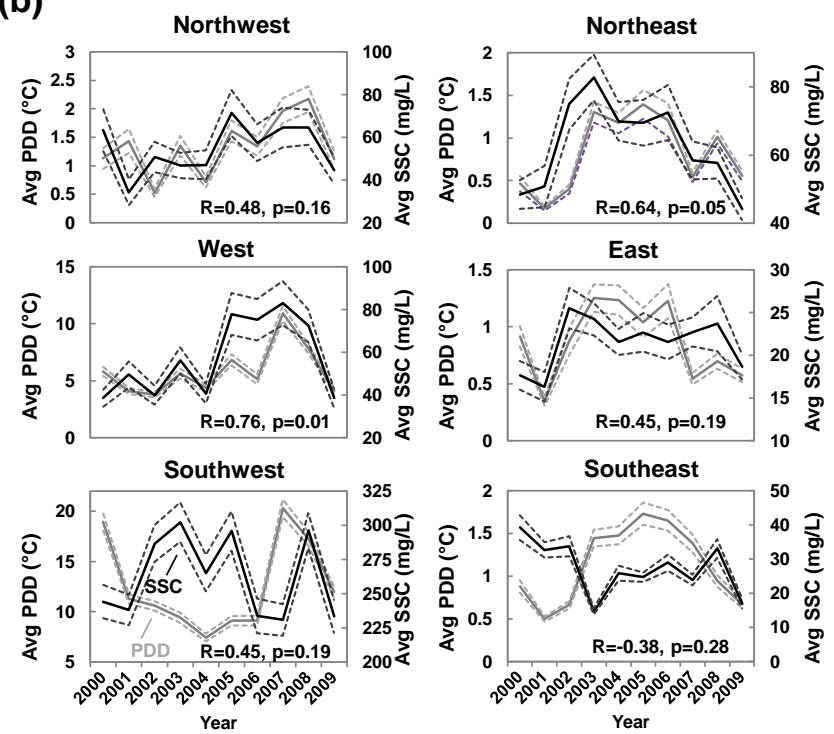

Fig. 6. Interannual variations of ice sheet PDD and plume SSC for the (a) entire ice sheet and for (b) each of the six regions from 2000-2009, with 95\% confidence intervals. The West and Northeast regions track each other rather well, while the Southwest and Southeast regions are fairly anti-correlated.

(d.o.y.) over 2000-2009, given at least two observations. While ice sheet melting inherently shows autocorrelation due to the inherently seasonal nature of solar radiation, autocorrelation is present also in fjord sediment concentration due to its reliance on meltwater transport, and therefore seasonal cross-correlations between the two datasets are naturally high. Correlations here will be used simply as a metric to show relative coherence between seasonal cycles, given the inherent autocorrelation. Cross-correlation is highest for the West and Southwest Regions $(R=0.81, p<0.001$, $R=0.86, p<0.001$, respectively, Figs. 7e and 8 ), especially Gridcell 14 in the Southwest $(R=0.92, p<0.001$, Table 1$)$. Differences between regions include PDD and SSC intensity and seasonal length of both datasets, with the Southwest Region (in particular Gridcells 17-19) exhibiting highest SSCs and highest PDDs, and longer periods of activity and persistent sediment suspension towards the end of the melt season. Plume decline occurs during PDD decline for all regions, but the Southwest indicates high-SSCs persisting during the decline in melt in contrast to Chu et al. (2009), that found apparent sediment exhaustion with sediment plume areas decreasing prior to declines in melt area. Plume onset gener- ally follows melt onset broadly in the western regions (Northwest, West, and Southwest), but the eastern regions (Southeast, East, and Northeast) show delayed plume onset as well as early melt onset. The Southeast Region is unique in that SSC is detected throughout the beginning of the melt season at low levels $\left(\sim 1.62-2.76 \mathrm{mg} \mathrm{l}^{-1}\right)$ indicating no arrival of sediment-rich meltwaters until June. The East Region has very low SSC $\left(\sim 0.83-0.97 \mathrm{mg} \mathrm{l}^{-1}\right)$ through the melt onset period, but much data are lost to the presence of sea ice until the end of May; the Northeast Region farther north shows even greater data loss with persistent sea ice until June.

\subsubsection{High frequency variability}

High frequency, near-daily time series from 2000-2009 of ice sheet PDD and plume SSC show high short term variability (Fig. 9). SSC values from 2010 are also shown (recall PMM5 PDD data were not available after 2009). The eastern regions (Southeast, East, and Northeast), all with much fewer PDDs, show a more variable melt season onset than the western regions. Overall, near-daily data generated by spatial and temporal aggregation do not correlate well and the temporal relationship between PDD and SSC matches better in average seasonal climatologies.

\subsection{Marine-terminating vs. land-terminating glacier outlets}

Plume characteristics vary with outlet glacier environment, here categorized into two broad types: land-terminating and marine-terminating. The spatial density of land-terminating outlet glaciers $\left(N_{\mathrm{L}}\right)$ shows a low positive correlation with averaged 2000-2009 SSC around the ice sheet $(R=0.32, p=$ 0.03 ), while the number of marine-terminating outlet glaciers $\left(N_{\mathrm{M}}\right)$ shows a negative correlation $(R=-0.42, p=0.003)$ (Fig. 7a). Normalizing the number of land-terminating and marine-terminating outlets by total number of outlets for each gridcell shows that the $F_{\mathrm{L}}$ is more strongly correlated with SSC than $N_{\mathrm{L}}(R=0.58, p<0.001)$. Outlet types for the most part cluster in regions, with the Southwest showing highest $F_{\mathrm{L}}(0.81)$ and the Southeast showing highest $F_{\mathrm{M}}$ (0.91) These overall trends reverse in northern regions, with relatively high $F_{\mathrm{L}}(0.59)$ in the Northeast and high $F_{\mathrm{M}}(0.60)$ in the Northwest. The geology of the ice-free area, one of the factors controlling the erosional susceptibility of the underlying bedrock, shows mostly latitudinal variation dominated by Archaean and early Proterozoic crystalline basement rocks (Geological Survey of Denmark and Greenland (GEUS), 2003). While geologic composition is only one of many factors in the production of sediment, softer rock types might be more easily eroded to produce more sediment, yet areas with highest SSCs are made up of hard gneisses that are likely to erode more slowly, possibly excluding geology as a controlling factor in fjord SSC. 

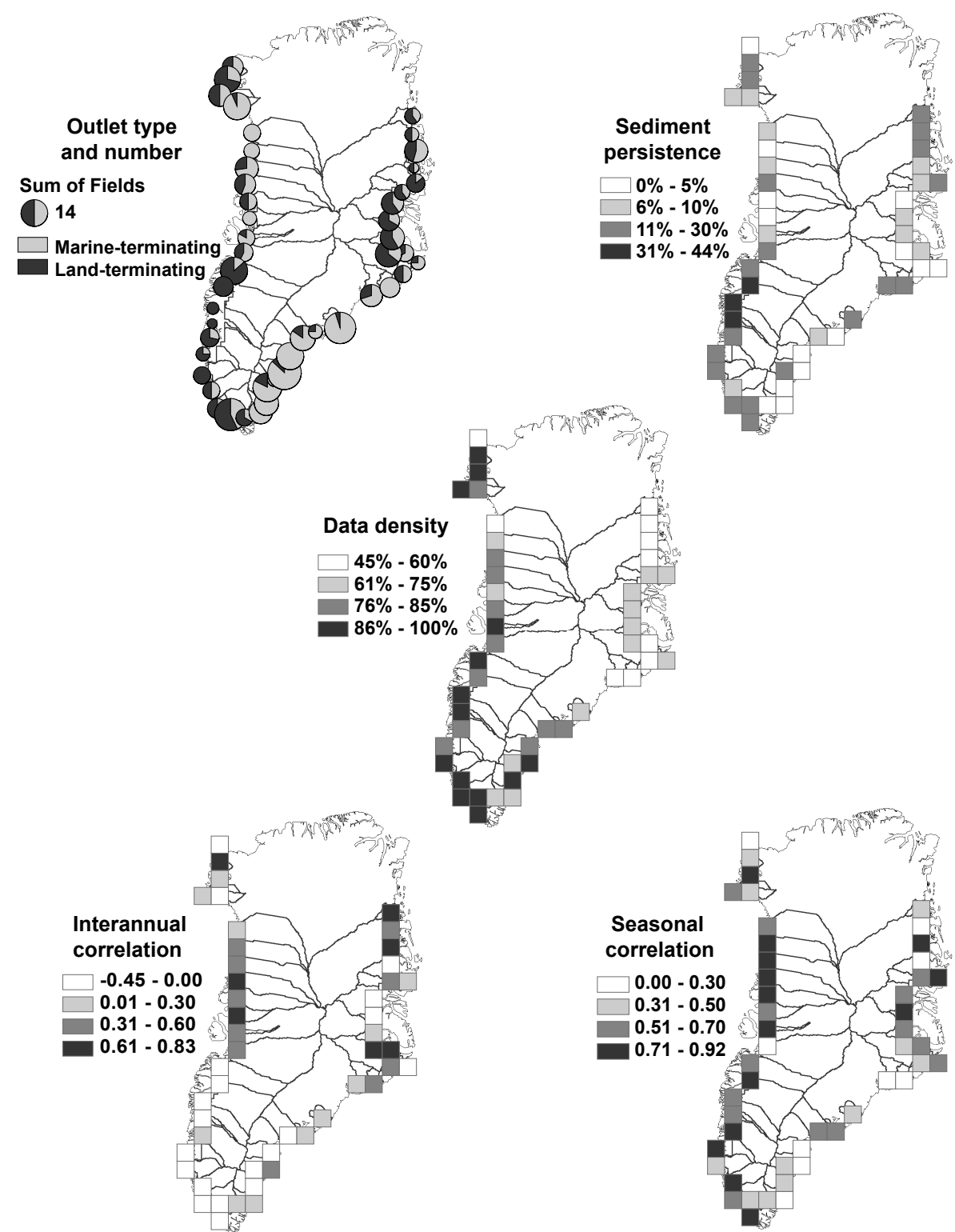

Fig. 7. Maps of parameters and analyses for each of the 47 gridcells. (a) Glacier outlet type shows the number and proportion of outlets in each gridcell that is land-terminating $\left(N_{\mathrm{L}}\right)$ or marine-terminating $\left(N_{\mathrm{M}}\right)$, with the size of the circle representing the total number of outlets reaching the fjord. (b) Sediment persistence $\left(F_{\mathrm{SSC}}\right)$ shows the fraction of open water days with sediment-rich water detected. (c) Data density $\left(\mathrm{DD}_{100 \mathrm{~km}}\right)$ shows the fraction of total days with open water detected (free of ice and clouds) for the aggregated $100 \mathrm{~km}$ data. $(\mathbf{d})$ Correlation between interannual averages of PDD and SSC over 2000-2009. (e) Correlation between mean seasonal cycles of PDD and SSC.

\subsection{Other factors}

$F_{\mathrm{SSC}}$, a measure of how long high SSC plumes persist, is highest in the southwest with highs also in the northwest and northeast (Fig. 7b). The Southwest Region, again containing Gridcell 13 and the Kangerlussuaq Fjord, shows that protected fjords and many land-terminating outlets in the southwest allow sediment to persist longer toward the end of the season.
$\mathrm{DD}_{100 \mathrm{~km}}$ has a positive spatial correlation $(R=0.42, p=$ 0.003 ) with SSC, highlighting areas in the southeast that often lose data due to iceberg calving yet still show low mean SSC (Fig. 7c). While $\mathrm{DD}_{100 \mathrm{~km}}$ is a measure of open water data retrieval, here it also mostly represents the predominance of icebergs and sea ice obscuring suspended sediment detection. This relationship represents another environmental factor affecting SSC detection and intensity; data density reflects both the outlet glacier environment and the climatic regime of the region. 

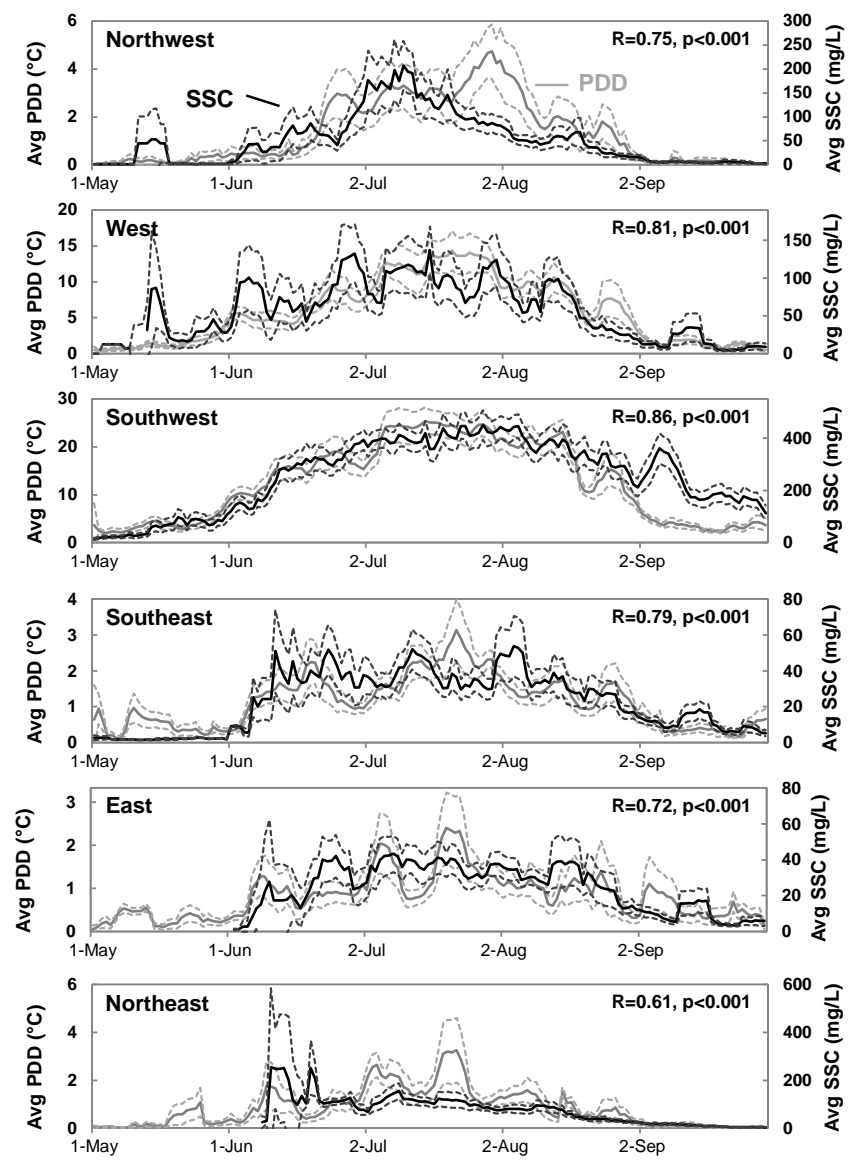

Fig. 8. Mean seasonal development of ice sheet PDD and downstream fjord SSC for each of the six regions. A seasonal climatology is calculated by taking day-of-year averages over 2000-2009, with $95 \%$ confidence intervals. Seasonal cycles broadly coincide with plume onset coincident with or after surface melt onset, though the East and Northeast regions show difficulty detecting onset due to presence of sea ice. High SSCs persist in the Southwest region during the waning of the melt season.

\section{Discussion}

MODIS-derived plume suspended sediment concentration (SSC) successfully maps average plume distribution, which is controlled by both ice sheet hydrology and outlet glacier type, around $\sim 80 \%$ of the Greenland coastline. Spatial variations in $10 \mathrm{yr}$ average positive degree days (PDDs), a proxy for meltwater generation on the ice sheet surface, is the most significant driver of spatial variations in $10 \mathrm{yr}$ mean SSC. While SSC data generated from $100 \mathrm{~km}$ gridcells greatly simplifies processes of sediment transport and dispersal, their correlation with ice sheet PDD indicates that higher ice sheet melting is linked to higher SSC in surrounding coastal waters. Likewise, ice sheet PDD only represents surface meltwater production and cannot be a proxy for runoff without the inclusion of refreezing, but this broad-scale asso- ciation reveals plume SSC as a viable signal of meltwater release. Furthermore, the corresponding seasonal development of PDD and SSC track each other rather well, with broadly coincident timings of melt onset and plume detection (Fig. 8). However, the Southeast and East Regions show delayed plume onset, lagging melt onset by $\sim 3-4$ weeks (a lag is also seen in the Northeast Region, but is due to delayed open water detection from sea ice, which may be obstructing a plume beneath the ice), whereas the western regions (Northwest, West, and Southwest) do not. In the Southeast and East Regions, despite delayed plume onset, plume growth coincides with the rising limb of PDD, but not in the Northeast. The Southwest Region reveals highly correlated seasonal climatologies of SSC and PDD (as averaged across each day-of-year over 2000-2009, Fig. 8), but also a unique lingering of high SSC persisting $\sim 1$ month during the waning of the melt season. This is notably different from the results of Chu et al. (2009), which suggest sediment exhaustion in Kangerlussuaq Fjord. This difference may be due to use of aggregated data, but is more likely due to the use of SSC rather than plume area. For example, in an elongate, protected fjord environment such as Kangerlussuaq Fjord, sediment may remain suspended but plume area may contract, possibly owing to circulation. This suggests that while ice sheet meltwater runoff is a dominant control of regional plume SSC development, fjord geometry in addition to outlet glacier types are also a factor.

Buoyant plumes are most readily detected downstream of rivers draining land-terminating glaciers, owing to high SSC ( $\sim 200-550 \mathrm{mg} \mathrm{l}^{-1}$ range on average) and minimal obstruction by calving ice. Marine-terminating glaciers, in contrast, produce lower SSC $\left(\sim 2-100 \mathrm{mg}^{-1}\right.$ range on average) and are often obstructed by icebergs and/or sea ice. Greenland's proglacial rivers, like other proglacial systems, are characterized by extremely high suspended sediment loads (e.g. 5$22000 \mathrm{mg} \mathrm{l}^{-1}$, Hasholt, 1996). Therefore, the spatial distribution of $10 \mathrm{yr}$ mean SSC reveals highest concentrations ( $\sim 200-500 \mathrm{mg}^{-1}$ ) in the fjords of the Southwest Region, where $F_{\mathrm{L}}$ (fraction of land-terminating glacier outlets) is highest. This differs from other studies that project highest total sediment export in areas with major calving glaciers such as the northeast and southeast (Hasholt, 1996). One reason for this contrast is that the present study identifies freshwater signals represented by fine sediments suspended in ocean surface waters, rather than total depth-integrated sediment export as measured in terrestrial rivers. Also, while other studies present SSC from rivers draining the ice sheet, here SSC is measured from fjord plumes, showing lower average values due to plume spreading and mixing with marine waters. Plume SSC may also be lower than river SSC if meltwater encounters lakes and floodplains with some sediment settling out before reaching the fjord, and may therefore be considered a conservative estimate in land-terminating outlet environments. Thus, the MODIS-derived SSCs presented here are useful for detecting fine sediments associated 

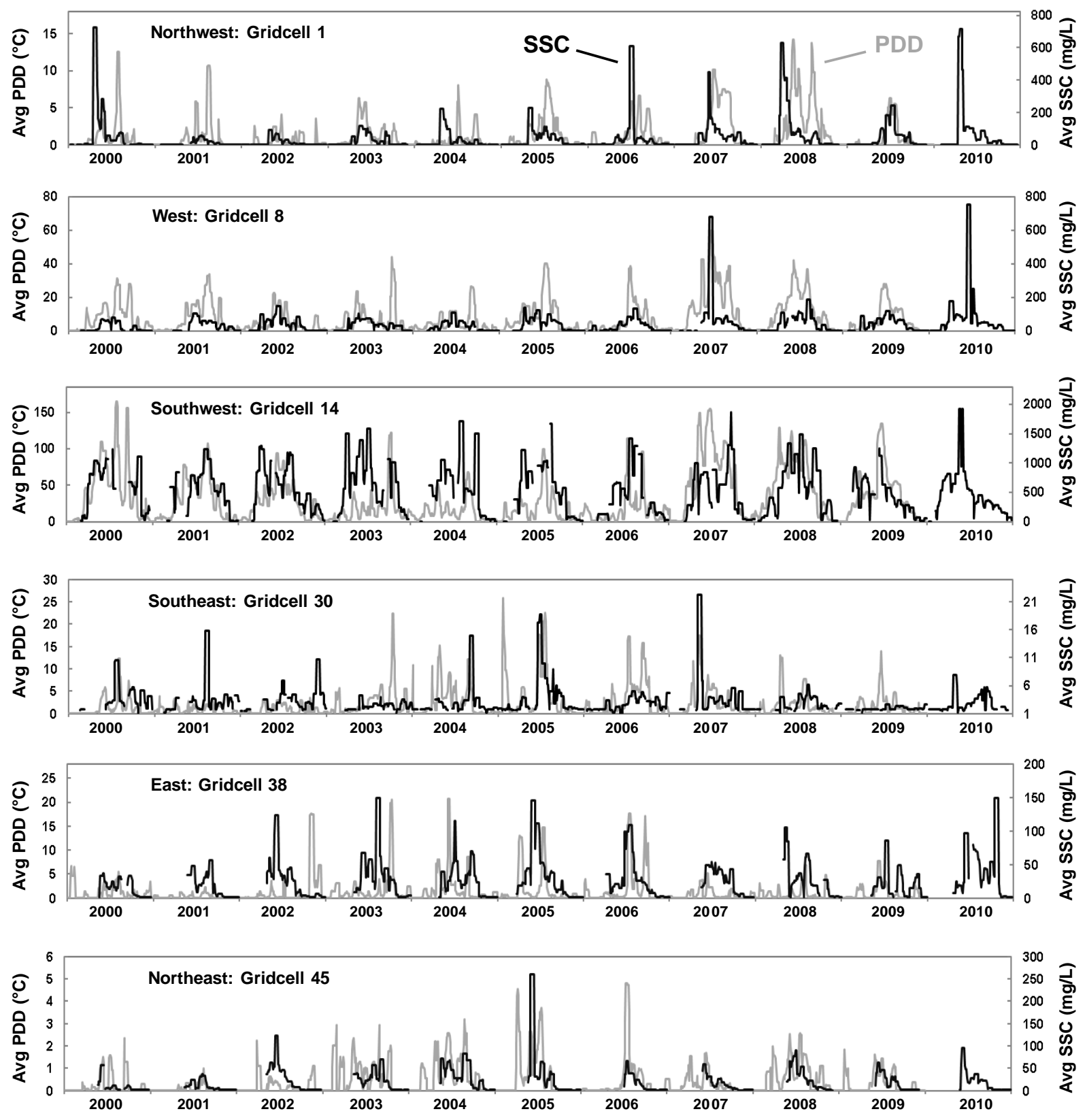

Fig. 9. Examples of high frequency time series of SSC and PDD for one gridcell in each of the six regions from 2000-2009. SSC is displayed for 2010 but not used in analysis due to PDD only being available up to 2009.

with freshwater release, but not total sediment export, are sensitive to outlet glacier type, and are lower than corresponding SSC values from terrestrial samples of meltwater runoff from the ice sheet.

While Chu et al. (2009) found a strong interannual relationship between ice sheet surface melt extent and plume area, the present study finds no corresponding coherence between ice sheet PDD and plume SSC. Indeed, Gridcell 13, representing the Kangerlussuaq Fjord studied by Chu et al. (2009) and McGrath et al. (2010), lacks any significant correlation $(R=-0.29, p=0.42)$ between the two variables on an interannual scale (Fig. 6b). This contrast stems solely from the use of SSCs rather than plume area, as the two melt datasets are highly correlated $(R=0.96, p<0.001)$. One reason for this may be the extrapolation of SSCs using a nonlinear empirical model, which also does not encompass the full range of sediment-rich water reflectances. Uncertainty in the model is difficult to quantify given that the limited number of field samples were only from two sites in the southwest, and therefore analysis of SSC has been dependent on 
averaged values at various scales for each gridcell. Future studies should provide more field samples from a wider array of plume states, particularly at the high-SSC range, to further refine the model. However, while plume dimensions are good indices of ice sheet hydrologic variations, their use is limited to unique environments like Kangerlussuaq Fjord, that develop large plumes at river mouths with consistent absence of calf and/or sea ice. The present approach, using SSC instead of plume dimensions, allows study of plumes in other coastal environments including marine-terminating outlet glaciers where calving ice confounds clear measurement of plume area or length.

Marine-terminating glacier outlets, particularly heavily calving ones (e.g. Helheim, Kangerdlugssuaq, Jakobshavn), provide complications to quantifying buoyant sediment plumes. While sediment from marine-terminating glacier bottom melting should rise to fjord surface waters owing to high buoyancy of the meltwater plume (Powell and Molnia, 1989), sediment plumes originating subglacially at depths up to $600 \mathrm{~m}$ below the fjord water surface can experience sedimentation as the plume rises to the surface when sediment fall velocities exceed the entrainment velocity of the plume (Mugford and Dowdeswell, 2011). Furthermore, the presence of a layer of freshwater at the fjord surface may prevent the plume from surfacing due to a loss in buoyancy upon mixing. In addition to meltwater, icebergs are the other major contributor of sediment to fjords (Andrews et al., 1994). Similar to subglacial meltwater inputs, sediment from icebergs melt out at depths of $\sim 100-400 \mathrm{~m}$, with a turbulent plume rising to the surface and sedimentation also occurring. Sediment originating from icebergs, while contributing to total sediment export, complicates the retrieval of plumes in this study because those sediments do not originate from terrestrial runoff sources. However, icebergs release sediment slowly as they melt, transporting sediment large distances downstream of the glacier front (Syvitski et al., 1996; Azetsu-Scott and Syvitski, 1999; Hasholt et al., 2006). Therefore, in fjords with moderate iceberg interference, any detection of a surface sediment plume (limited by fjord spatial sampling $\sim 15-20 \mathrm{~km}$ from the glacier front) likely reflects input of ice sheet meltwater runoff rather than sediment from icebergs. Though heavily calving glaciers are very important to mass loss and sediment export, the sikussaks of dense icebergs circulating within the upper fjord environment prevent plume detection and are removed with a data density restriction. Similarly, while the northern part of Greenland is of interest due to extensive bottom melting (rather than iceberg calving as the primary ablation mechanism, Reeh et al., 1999), data scarcity from persistent sea ice precludes adequate SSC recovery from MODIS reflectance products. Therefore, higher spatial resolution sensors are required to study plume characteristics in areas of pervasive iceberg and sea ice cover.

At high temporal frequencies (near-daily, Fig. 9) ice sheet PDD and plume SSC are generally uncoupled, suggesting that complex processes of meltwater routing and sediment transport are not captured in a simple relationship between broad-scale representations of ice sheet meltwater production and buoyant sediment plumess. Furthermore, spatiotemporal aggregation is not effective for resolving the wellknown temporal resolution limitations of MODIS in narrow fjord environments (Chu et al., 2009; McGrath et al., 2009). This lack of correlation at near-daily time scales is perhaps unsurprising with the very large $100 \mathrm{~km}$ gridcell aggregations required to produce near-daily time series. Also, other physical factors besides terrestrial runoff influence plume dynamics in the short term, including tides and wind (e.g. Dowdeswell and Cromack, 1991; Whitney and Garvine, 2005; Halverson and Pawlowicz, 2008). Detecting short-term (days to $\sim 1$ week) variations in terrestrial runoff from sediment plumes remains challenging from a satellite remote sensing approach.

While this broad-scale view of sediment plumes around the ice sheet presents them as signals of meltwater release to the coast, sources of uncertainty limit these datasets for quantifying true runoff flux and studying ice sheet hydrology on a process-scale. As a proxy for meltwater runoff from the ice sheet, PDD does not take into account meltwater routing or storage in the glacier and in proglacial systems, which will affect both timing and intensity of meltwater release. Future studies need to incorporate runoff models tuned by in situ discharge observations such as Mernild and Hasholt (2009) and Rennermalm et al. (2011). As discussed above, using SSC to represent plume characteristics has its limitations due to the site-specific calibration of MODIS reflectances, the lack of validation for higher extrapolated SSC values from the empirical model, and the spatial aggregation used to overcome the poor temporal sampling. This scale of analysis obscures many physical processes, from ice sheet meltwater routing, to sediment transport, to mixing of fjord water masses. A more in-depth understanding of the various states, processes, and relationships between ice sheet hydrology and sediment dispersal from outlet glaciers is required for remote sensing of plumes to become a useful tool in assessing total meltwater flux to the ocean.

\section{Conclusions}

This study provides a first synoptic assessment of remotelysensed buoyant coastal sediment plumes around Greenland, and links them to ice sheet runoff from land- and marineterminating outlet glaciers. Meltwater production on the ice sheet surface, as approximated by PDD, is the most significant driver of spatial variations in suspended sediment concentrations of coastal ocean waters. On average, land-terminating outlet glaciers produce higher plume SSCs than marine-terminating outlet glaciers, although MODIS retrievals from the latter are often obstructed by icebergs. Despite known complexities in plume formation and 
development processes, remotely sensed sediment plumes appear to supply viable evidence of meltwater release. As such, their detection and monitoring from space represents one of the few ways to observe hydrologic release of meltwater from the Greenland ice sheet to the global ocean over broad spatial and temporal scales.

Acknowledgements. This research was supported by the NASA Cryosphere Program managed by Thomas Wagner (grant NNX11AQ38G) and a fellowship from the NASA Graduate Student Researchers Program (grant number NNX09AM25H), and the MODIS imagery was also provided by NASA.. We thank R. Carlos and S. Jimenez for help in MODIS downloading, and K. Savage for help in MODIS processing and classification validation. We also thank P. Christoffersen and two anonymous reviewers for their detailed and constructive comments that improved the manuscript.

Edited by: C. O'Cofaigh

\section{References}

Abdalati, W. and K. Steffen: Snowmelt on the Greenland ice sheet as derived from passive microwave satellite data, J. Climate, 10, 165-175, 1997.

Amundson, J. M., Truffer, M., Luthi, M. P., Fahnestock, M., West, M., and Motyka, R. J.: Glacier, fjord, and seismic response to recent large calving events, Jakobshavn Isbrae, Greenland, Geophys. Res. Lett., 35, L22501, doi:10.1029/2008g1035281, 2008.

Andersen, M. L., Larsen, T. B., Nettles, M., Elosegui, P., van As, D., Hamilton, G. S., Stearns, L. A., Davis, J. L., Ahlstrom, A. P., de Juan, J., Ekstrom, G., Stenseng, L., Khan, S. A., Forsberg, R., and Dahl-Jensen, D.: Spatial and temporal melt variability at Helheim Glacier, East Greenland, and its effect on ice dynamics, J. Geophys. Res.-Earth, 115, F04041, doi:10.1029/2010jf001760, 2010.

Andrews, J. T., Milliman, J. D., Jennings, A. E., Rynes, N., and Dwyer, J.: Sediment thicknesses and Holocene glacial marine sedimentation-rates in 3 East Greenland fjords (ca. $68^{\circ} \mathrm{N}, \mathrm{J}$. Geol., 102, 669-683, 1994.

Azetsu-Scott, K. and Syvitski, J. P. M.: Influence of melting icebergs on distribution, characteristics and transport of marine particles in an East Greenland fjord, J. Geophys. Res.-Oceans, 104, 5321-5328, 1999.

Bartholomew, I., Nienow, P., Mair, D., Hubbard, A., King, M. A., and Sole, A.: Seasonal evolution of subglacial drainage and acceleration in a Greenland outlet glacier, Nature Geosci., 3, 408411, 2010

Bhattacharya, I., Jezek, K. C., Wang, L., and Liu, H. X.: Surface melt area variability of the Greenland ice sheet: 1979-2008, Geophys. Res. Lett., 36, 2009.

Bøggild, C. E., Knudby, C. J., Knudsen, M. B., and Starzer, W.: Snowmelt and runoff modelling of an Arctic hydrological basin in west Greenland, Hydrol. Process., 13, 1989-2002, 1999.

Bougamont, M., Bamber, J. L., Ridley, J. K., Gladstone, R. M., Greuell, W., Hanna, E., Payne, A. J., and Rutt, I.: Impact of model physics on estimating the surface mass balance of the Greenland ice sheet, Geophys. Res. Lett., 34, L17501, doi:10.1029/2007GL030700, 2007.
Bowers, D. G., Boudjelas, S., and Marker, G. E. L.: The distribution of fine suspended sediments in the surface waters of the Irish Sea and its relation to tidal stirring, Int. J. Remote Sens., 19, 2789 2805, 1998.

Box, J. E. and Ski, K.: Remote sounding of Greenland supraglacial melt lakes: implications for subglacial hydraulics, J. Glaciol., 53, 257-265, 2007.

Box, J. E., Bromwich D. H., Veenhuis, B. A., Bai, L. S., Stroeve, J. C., Rogers, J. C., Steffen, K., Haran, T., and Wang, S. H.: Greenland ice sheet surface mass balance variability (1988-2004) from calibrated polar MM5 output, J. Climate, 19, 2783-2800, 2006.

Box, J. E., Yang, L., Bromwich, D. H., and Bai, L. S.: Greenland Ice Sheet Surface Air Temperature Variability: 1840-2007, J. Climate, 22, 4029-4049, 2009.

Burgess, E. W., Forster, R. R., Box, J. E., Mosley-Thompson, E., Bromwich, D. H., Bales, R. C., and Smith, L. C.: A spatially calibrated model of annual accumulation rate on the Greenland Ice Sheet (1958-2007), J. Geophys. Res.-Earth, 115, F02004, doi:10.1029/2009jf001293, 2010.

Busskamp, R. and Hasholt, B.: Coarse bed load transport in a glacial valley, Sermilik, South East Greenland, Z. Geomorphol., 40, 349-358, 1996.

Castaing, P. and Allen, G. P.: Mechanisms controlling seaward escape of suspended sediment from the Gironde - a macrotidal estuary in France, Mar. Geol., 40, 101-118, 1981.

Catania, G. A. and Neumann, T. A.: Persistent englacial drainage features in the Greenland Ice Sheet, Geophys. Res. Lett., 37, L02501, doi:10.1029/2009g1041108, 2010.

Chen, J. L., Wilson, C. R., and Tapley, B. D.: Satellite gravity measurements confirm accelerated melting of Greenland ice sheet, Science, 313, 1958-1960, 2006.

Chu, V. W., Smith, L. C., Rennermalm, A. K., Forster, R. R., Box, J. E., and Reeh, N.: Sediment plume response to surface melting and supraglacial lake drainages on the Greenland ice sheet, J. Glaciol., 55, 1072-1082, 2009.

Colgan, W., Rajaram, H. Anderson, R., Steffen, K., Phillips, T., Joughin, I., Zwally, H. J., and Abdalati, W.: The annual glaciohydrology cycle in the ablation zone of the Greenland ice sheet, Part 1: Hydrology model, J. Glaciol., 57, 697-709, 2011.

Curran, P. J. and Novo, E. M. M.: The relationship between suspended sediment concentration and remotely sensed spectral radiance - A review, Journal of Coastal Research, 4, 351-368, 1988.

Das, S. B., Joughin, I., Behn, M. D., Howat, I. M., King, M. A., Lizarralde, D., and Bhatia, M. P.: Fracture propagation to the base of the Greenland Ice Sheet during supraglacial lake drainage, Science, 320, 778-781, 2008.

Dowdeswell, J. A. and Cromack, M.: Behavior of a glacier-derived suspended sediment plume in a small Arctic inlet, J. Geol., 99, 111-123, 1991.

Doxaran, D., Froidefond, J. M., Lavender, S., and Castaing, P.: Spectral signature of highly turbid waters - Application with SPOT data to quantify suspended particulate matter concentrations, Remote Sens. Environ., 81, 149-161, 2002.

Ettema, J., van den Broeke, M. R., van Meijgaard, E., van de Berg, W. J., Bamber, J. L., Box, J. E., and Bales, R. C.: Higher surface mass balance of the Greenland ice sheet revealed by highresolution climate modeling, Geophys. Res. Lett., 36, L12501, doi:10.1029/2009GL038110, 2009. 
Fettweis, X.: Reconstruction of the 1979-2006 Greenland ice sheet surface mass balance using the regional climate model MAR, The Cryosphere, 1, 21-40, doi:10.5194/tc-1-21-2007, 2007.

Fettweis, X., Hanna, E., Gallée, H., Huybrechts, P., and Erpicum, M.: Estimation of the Greenland ice sheet surface mass balance for the 20th and 21st centuries, The Cryosphere, 2, 117-129, doi:10.5194/tc-2-117-2008, 2008

Georgiou, S., Shepherd, A., McMillan, M., and Nienow, P.: Seasonal evolution of supraglacial lake volume from ASTER imagery, Ann. of Glaciol., 50, 95-100, 2009.

Gurnell, A., Hannah, D., and Lawler, D.: Suspended sediment yield from glacier basins, in: Erosion and Sediment Yield: Global and Regional Perspectives, edited by: Walling, D. E. and Webb, B. W., IAHS, 236, 97-104, 1996.

Hall, D. K., Williams, R. S., Luthcke, S. B., and Digirolamo, N. E.,: Greenland ice sheet surface temperature, melt and mass loss: 2000-2006, J. Glaciol., 53, 81-93, 2008.

Hallet, B., Hunter, L., and Bogen, J.: Rates of erosion and sediment evacuation by glaciers: A review of field data and their implications, Global Planet. Change, 12, 213-235, 1996.

Halverson, M. J. and Pawlowicz, R.: Estuarine forcing of a river plume by river flow and tides, J. Geophys.Res.-Oceans, 113, C09033, doi:10.1029/2008jc004844, 2008.

Hammer, K. M. and Smith, N. D.: Sediment production and transport in a proglacial stream - Hilda Glacier, Alberta, Canada, Boreas, 12, 91-106, 1983.

Hanna, E., Huybrechts, P., Steffen, K., Cappelen, J., Huff, R., Shuman, C., Irvine-Fynn, T., Wise, S., and Griffiths, M.: Increased runoff from melt from the Greenland Ice Sheet: A response to global warming, J. Climate, 21, 331-341, 2008.

Hasholt, B.: Sediment transport in Greenland, Erosion and Sediment Yield: Global and Regional Perspectives (Proceedings of the Exeter Symposium), IAHS, 1996.

Hasholt, B. and Mernild S. H.: Hydrology, sediment transport and water resources of Ammassalik Island, SE Greenland, Geogr.Tidsskr., 108, 73-95, 2008.

Hasholt, B., Bobrovitskaya, N., Bogen, J., McNamara, J., Mernild, S. H., Milburn, D., and Walling, D. E.: Sediment transport to the Arctic Ocean and adjoining cold oceans, Nord. Hydrol., 37, 413-432, 2006.

Hock, R.: Temperature index melt modelling in mountain areas, J. Hydrol., 282, 104-115, 2003.

Holland, D. M., Thomas, R. H., De Young, B., Ribergaard, M. H., and Lyberth, B.: Acceleration of Jakobshavn Isbrae triggered by warm subsurface ocean waters, Nature Geosci., 1, 659-664, 2008.

Howat, I. M., Joughin, I., and Scambos, T. A.: Rapid changes in ice discharge from Greenland outlet glaciers, Science, 315, 15591561, 2007.

Hu, C. M., Chen, Z. Q., Clayton, T. D., Swarzenski, P., Brock, J. C., and Muller-Karger, F. E.: Assessment of estuarine water-quality indicators using MODIS medium-resolution bands: Initial results from Tampa Bay, FL, Remote Sens. Environ., 93, 423-441, 2004.

Joughin, I., Das, S. B., King, M. A., Smith, B. E., Howat, I. M., and Moon, T.: Seasonal speedup along the western flank of the Greenland Ice Sheet, Science, 320, 781-783, 2008.

Joughin, I., Smith, B. E., Howat, I. M., Scambos, T., and Moon, T.: Greenland flow variability from ice-sheet-wide velocity map- ping, J. Glaciol., 56, 415-430, 2010.

Joughin, I., Tulaczyk, S., Fahnestock, M., and Kwok, R.: A minisurge on the Ryder Glacier, Greenland, observed by satellite radar interferometry, Science, 274, 228-230, 1996.

Khan, S. A., Wahr, J., Bevis, M., Velicogna, I., and Kendrick, E.: Spread of ice mass loss into northwest Greenland observed by GRACE and GPS, Geophys. Res. Lett., 37, L06501, doi:10.1029/2010GL042460, 2010.

Knudsen, N. T., Yde, J. C., and Gasser, G.: Suspended sediment transport in glacial meltwater during the initial quiescent phase after a major surge event at Kuannersuit Glacier, Greenland, Geogr. Tidsskr., 107, 1-7, 2007.

Krabill, W., Hanna, E., Huybrechts, P., Abdalati, W., Cappelen, J., Csatho, B., Frederick, E., Manizade, S., Martin, C., Sonntag, J. Swift, R., Thomas, R., and Yungel, J.: Greenland Ice Sheet: Increased coastal thinning, Geophys. Res. Lett., 31, L24402, doi:10.1029/2004GL021533, 2004.

Lewis, S. M. and Smith, L. C.: Hydrologic drainage of the Greenland Ice Sheet, Hydrol. Process., 23, 2004-2011, 2009.

Lihan, T., Saitoh, S. I., Iida, T., Hirawake, T., and Iida, K.: Satellitemeasured temporal and spatial variability of the Tokachi River plume, Estuar. Coast. Shelf Sci., 78, 237-249, 2008.

Lund-Hansen, L. C., Andersen, T. J., Nielsen, M. H., and Pejrup, M.: Suspended Matter, chl- $a$, CDOM, Grain Sizes, and Optical Properties in the Arctic Fjord-Type Estuary, Kangerlussuaq, West Greenland During Summer, Estuar. Coast., 33, 1442-1451, 2010.

Luthcke, S. B., Zwally, H. J., Abdalati, W., Rowlands, D. D., Ray, R. D., Nerem, R. S., Lemoine, F. G., McCarthy, J. J., and Chinn, D. S.: Recent Greenland ice mass loss by drainage system from satellite gravity observations, Science, 314, 1286-1289, 2006.

McGrath, D., Steffen, K., Overeem, I., Mernild, S. H., Hasholt, B., and van den Broeke, M.: Sediment plumes as a proxy for local ice-sheet runoff in Kangerlussuaq Fjord, West Greenland, J. Glaciol., 56, 813-821, 2010.

Mernild, S. H. and Hasholt B.: Observed runoff, jokulhlaups and suspended sediment load from the Greenland ice sheet at Kangerlussuaq, West Greenland, 2007 and 2008, J. Glaciol., 55, 855858, 2009.

Mernild, S. H., Howat, I. M., Ahn, Y., Liston, G. E., Steffen, K., Jakobsen, B. H., Hasholt, B., Fog, B., and van As, D.: Freshwater flux to Sermilik Fjord, SE Greenland, The Cryosphere, 4, 453465, doi:10.5194/tc-4-453-2010, 2010.

Mernild, S. H., Liston, G. E., Hiemstra, C. A., Christensen, J. H., Stendel, M., and Hasholt, B.: Surface Mass Balance and Runoff Modeling Using HIRHAM4 RCM at Kangerlussuaq (Sondre Stromfjord), West Greenland, 1950-2080, J. Climate, 24, 609623, 2011.

Mernild, S. H., Liston, G. E., Steffen, K., van den Broeke, M., and Hasholt, B.: Runoff and mass-balance simulations from the Greenland Ice Sheet at Kangerlussuaq (Søndre Strømfjord) in a $30 \mathrm{yr}$ perspective, 1979-2008, The Cryosphere, 4, 231-242, doi:10.5194/tc-4-231-2010, 2010.

Miller, R. L. and McKee B. A.: Using MODIS Terra $250 \mathrm{~m}$ imagery to map concentrations of total suspended matter in coastal waters, Remote Sens. Environ., 93, 259-266, 2004.

Mote, T. L.: Greenland surface melt trends 1973-2007: Evidence of a large increase in 2007, Geophys. Res. Lett., 34, L22507, doi:10.1029/2007GL031976, 2007. 
Mugford, R. I. and Dowdeswell, J. A.: Modeling iceberg-rafted sedimentation in high-latitude fjord environments, J. Geophys. Res.-Earth, 115, F03024, doi:10.1029/2009jf001564, 2010.

Mugford, R. I. and Dowdeswell, J. A.: Modeling glacial meltwater plume dynamics and sedimentation in high-latitude fjords, J. Geophys. Res.-Earth, 116,F01023, doi:10.1029/2010jf001735, 2011.

Mulder, T. and Syvitski, J. P. M.: Turbidity currents generated at river mouths during exceptional discharges to the world oceans, J. Geol. 103, 285-299, 2005.

Ohmura, A.: Physical basis for the temperature-based melt-index method, J. App. Meteorol., 40, 753-761, 2001.

Palmer, S., Shepherd, A., Nienow, P., and Joughin, I.: Seasonal speedup of the Greenland Ice Sheet linked to routing of surface water, Earth Planet. Sci. Lett., 302, 423-428, 2011.

Pfeffer, W. T., Harper, J. T., and O’Neel, S.: Kinematic constraints on glacier contributions to 21st-century sea-level rise, Science, 321, 1340-1343, 2008.

Powell, R. D. and Molnia, B. F.: Glacimarine sedimentary processes, facies and morphology of the South-Southeast Alaska shelf and fjords, Mar. Geol., 85, 359-390, 1998.

Pritchard, H. D., Arthern, R. J., Vaughan, D. G., and Edwards, L. A.: Extensive dynamic thinning on the margins of the Greenland and Antarctic ice sheets, Nature, 461, 971-975, 2009.

Rasch, M., Elberling, B., Jakobsen, B. H., and Hasholt, B.: Highresolution measurements of water discharge, sediment and solute transport in the river Zackenbergelven, Northeast Greenland, Arct. Antarctic Alp. Res., 32, 336-345, 2000.

Reeh, N., Mayer, C., Miller, H., Thomsen, H. H., and Weidick, A.: Present and past climate control on fjord glaciations in Greenland: Implications for IRD-deposition in the sea, Geophys. Res. Lett., 26, 1039-1042, 1999.

Rennermalm, A. K., Smith, L. C., Chu, V. W., Forster, R. R., Box, J. E., and Hagedorn, B.: Proglacial river dataset from the Akuliarusiarsuup Kuua River northern tributary, Southwest Greenland, 2008-2010, Earth Syst. Sci. Data Discuss., 4, 71-97, doi:10.5194/essdd-4-71-2011, 2011.

Rignot, E. and Kanagaratnam, P.: Changes in the velocity structure of the Greenland ice sheet, Science, 311, 986-990, 2006.

Rignot, E. and Steffen, K.: Channelized bottom melting and stability of floating ice shelves, Geophys. Res. Lett., 35, L02503, doi:10.1029/2007g1031765, 2008.

Rignot, E., Box, J. E., Burgess, E., and Hanna E.: Mass balance of the Greenland ice sheet from 1958 to 2007, Geophys. Rese. Lett., 35, L20502, doi:10.1029/2008g1035417, 2008.

Rignot, E., Braaten, D., Gogineni, S. P., Krabill, W. B., and McConnell, J. R.: Rapid ice discharge from southeast Greenland glaciers, Geophys. Res. Lett., 31, L10401, doi:10.1029/2004GL019474, 2004.

Russell, A. J.: Controls on the sedimentology of an ice-contact jokulhlaup-dominated delta, Kangerlussuaq, west Greenland, Sediment. Geol., 193, 131-148, 2007.

Schneider, T. and Bronge, C.: Suspended sediment transport in the Storglaciaren drainage basin, Geogr. Ann. A, 78, 155-161, 1996.

Schoof, C.: Ice-sheet acceleration driven by melt supply variability, Nature, 468, 803-806, 2010.

Shepherd, A., Hubbard, A., Nienow, P., King, M., McMillan, M., and Joughin, I.: Greenland ice sheet motion coupled with daily melting in late summer, Geophys. Res.Lett., 36, L01501,
L01501, doi:10.1029/2008g1035758, 2009.

Smith, L. C., Sheng, Y. W., Forster, R. R., Steffen, K., Frey, K. E., and Alsdorf, D. E.: Melting of small Arctic ice caps observed from ERS scatterometer time series, Geophys. Res. Lett., 30, L01501, doi:10.1029/2008g1035758, 2003.

Sole, A. J., Mair, D. W. F., Nienow, P. W., Bartholomew, I. D., King, M. A., Burke, M. J., and Joughin, I.: Seasonal speedup of a Greenland marine-terminating outlet glacier forced by surface melt-induced changes in subglacial hydrology, J. Geophys. Res.Earth, 116, F03014, doi:10.1029/2010jf001948, 2011.

Stott, T. A. and Grove, J. R.: Short-term discharge and suspended sediment fluctuations in the proglacial Skeldal River, North-east Greenland, Hydrol. Process., 15, 407-423, 2001.

Straneo, F., Hamilton, G. S., Sutherland, D. A., Stearns, L. A., Davidson, F., Hammill, M. O., Stenson, G. B., and RosingAsvid, A.: Rapid circulation of warm subtropical waters in a major glacial fjord in East Greenland, Nat. Geosci., 3, 182-186, 2010.

Stumpf, R. P., Gelfenbaum, G., and Pennock, J. R.: Wind and tidal forcing of a buoyant plume, Mobile Bay, Alabama, Cont. Shelf Res., 13, 1281-1301, 1993.

Sundal, A. V., Shepherd, A., Nienow, P., Hanna, E., Palmer, S., and Huybrechts, P.: Evolution of supra-glacial lakes across the Greenland Ice Sheet, Rem. Sens. Environ, 113, 2164-2171, 2009.

Syvitski, J. P. M., Andrews, J. T., and Dowdeswell, J. A.: Sediment deposition in an iceberg-dominated glacimarine environment, East Greenland: Basin fill implications, Global Planet. Change, 12, 251-270, 1996.

Syvitski, J. P. M., Asprey, K. W., Clattenburg, D. A., and Hodge, G. D.: The prodelta environment of a fjord - suspended particle dynamics, Sedimentology, 32, 83-107, 1985.

Tedesco, M.: Snowmelt detection over the Greenland ice sheet from SSM/I brightness temperature daily variations, Geophys. Res. Lett., 34, L02504, doi:10.1029/2006g1028466, 2007.

Tedesco, M., Serreze, M., and Fettweis, X.: Diagnosing the extreme surface melt event over southwestern Greenland in 2007, The Cryosphere, 2, 159-166, doi:10.5194/tc-2-159-2008, 2008.

Thomas, A. C. and Weatherbee, R. A.: Satellite-measured temporal variability of the Columbia River plume, Remote Sens. Environ., 100, 167-178, 2006.

Thomas, R., Frederick, E., Krabill, W., Manizade, S., and Martin, C.: Recent changes on Greenland outlet glaciers, J. Glaciol., 55, 147-162, 2009.

Thomas, R. H., Abdalati, W., Frederick E., Krabill, W. B., Manizade, S., and Steffen, K.: Investigation of surface melting and dynamic thinning on Jakobshavn Isbrae, Greenland, J. Glaciol., 49, 231-239, 2003.

van de Wal, R. S. W., Boot, W., van den Broeke, M. R., Smeets, C., Reijmer, C. H., Donker, J. J. A., and Oerlemans, J.: Large and rapid melt-induced velocity changes in the ablation zone of the Greenland Ice Sheet, Science, 321, 111-113, 2008.

van den Broeke, M., Smeets, P., Ettema, J., van der Veen, C., van de Wal, R., and Oerlemans, J.: Partitioning recent Greenland mass loss, Science, 326, 984-986, 2009.

van den Broeke, M., Smeets, P., Ettema, J., van der Veen, C., van de Wal, R., and Oerlemans, J.: Partitioning of melt energy and meltwater fluxes in the ablation zone of the west Greenland ice sheet, The Cryosphere, 2, 179-189, doi:10.5194/tc-2-179-2008, 
2008.

Velicogna, I.: Increasing rates of ice mass loss from the Greenland and Antarctic ice sheets revealed by GRACE, Geophys. Res. Lett., 36, L19503, doi:10.1029/2009g1040222, 2009.

Vermote, E. F., El Saleous, N. Z., and Justice, C. O.: Atmospheric correction of MODIS data in the visible to middle infrared: first results, Remote Sens. Environ., 83, 97-111, 2002.

Whitney, M. M. and Garvine, R. W.: Wind influence on a coastal buoyant outflow, J. Geophys. Res.-Oceans, 110, C03014, doi:10.1029/2003jc002261, 2005.

Willis, I. C., Richards, K. S., and Sharp, M. J.: Links between proglacial stream suspended sediment dynamics, glacier hydrology and glacier motion at Midtdalsbreen, Norway, Hydrol. Process., 10, 629-648, 1996.
Yin, J., Overpeck, J. T., Griffies, S. M., Hu, A., Russell, J. L., and Stouffer, R. J.: Different magnitudes of projected subsurface ocean warming around Greenland and Antarctica, Nat. Geosci., 4, 524, 2011.

Zwally, H. J., Abdalati, W., Herring, T., Larson, K., Saba, J., and Steffen, K.: Surface melt-induced acceleration of Greenland icesheet flow, Science, 297, 218-222, 2002. 